\title{
Revision of thelodonts, acanthodians, conodonts, and the depositional environments in the Burgen outlier (Ludlow, Silurian) of Gotland, Sweden
}

\author{
Emilia Jarochowska1, Oskar Bremer ${ }^{2}$, Alexandra Yiu ${ }^{1}$, Tiiu \\ Märss ${ }^{3}$, Henning Blom², Thomas Mörss ${ }^{4}$, Vivi Vajda ${ }^{4}$
}

${ }^{1}$ GeoZentrum Nordbayern, Fachgruppe Paläoumwelt, University of Erlangen-Nürnberg, Loewenichstr. 28, 91054 Erlangen, Germany; Emilia.Jarochowska@fau.de and alexandra_yiu@ymail.com

2Uppsala University, Department of Organismal Biology, Norbyvägen 18A, SE-752 36,

Uppsala, Sweden; oskar.bremer@ebc.uu.se and Henning.Blom@ebc.uu.se

3Department of Geology at Tallinn University of Technology, Ehitajate tee 5, 19086 Tallinn, Estonia; tiiu.marss@taltech.ee

${ }^{4}$ Department of Palaeobiology, Swedish Museum of Natural History, P.O. Box 50007, SE-104

05, Stockholm, Sweden; Thomas.Mors@nrm.se and Vivi.Vajda@nrm.se

Corresponding author: Emilia.Jarochowska@fau.de https://orcid.org/0000-0001-8937-9405

https://twitter.com/Emiliagnathus

This is a post-print of a peer-reviewed article accepted for publication in GFF

under the following link: $\underline{\text { ttps://doi.org/10.1080/11035897.2021.1907441 }}$

Please cite the final peer-reviewed version.

\begin{abstract}
Ludfordian strata exposed in the Burgen outlier in eastern Gotland record a time of initial faunal recovery after a global environmental perturbation manifested in the Ludfordian Carbon Isotope Excursion (LCIE). Vertebrate microfossils in the collection of the late Lennart Jeppsson, hosted at the Swedish Museum of Natural History, hold the key to reconstruct the dynamics of faunal immigration and diversification during the decline of the LCIE, but the stratigraphic relationships of the strata have been debated. Historically, they had been
\end{abstract}


placed in the Burgsvik Formation, which included the Burgsvik Sandstone and the Burgsvik Oolite members. We revise the fauna in the Jeppsson collection and characterize key outcrops of Burgen and Kapellet. The former Burgsvik Oolite Member is here revised as the Burgen Oolite Formation. In the Burgen outlier, back-shoal facies of this formation are represented and their position in the Ozarkodina snajdri Biozone is supported. The shallowmarine position compared to the coeval strata in southern Gotland is reflected in the higher $\delta^{13} C_{\text {carb }}$ values, reaching $+9.2 \%$. The back-shoal succession includes high-diversity metazoan reefs, which indicate a complete recovery of the carbonate producers as the LCIE declined. The impoverishment of conodonts associated with the LCIE in southern Gotland might be a product of facies preferences, as the diverse environments in the outlier yielded all 21 species known from the formation. Fish diversity also returned to normal levels as the LCIE declined, with a minimum of nine species. In line with previous reports, thelodont scales appear to dominate samples from the Burgen outlier.

\section{Keywords}

acanthodians, biostratigraphy, Burgsvik Formation, Ludlow, thelodonts, Lau event, carbon isotope excursion, extinction, recovery, palynology

\section{Introduction}

The Ludlow-aged strata placed in the Burgsvik Formation (Fig. 1) in Gotland, Sweden, represents an important archive of the evolution of early vertebrates (Fredholm, 1989, 1990; Märss, 1992; Bremer \& Blom, 2015; Bremer et al., 2020) and plants (see Mehlqvist et al., 2015 and references therein), and of global sea-level and palaeoclimate perturbations (Samtleben et al., 2000; Calner, 2005; Eriksson \& Calner, 2008; Kozłowski \& Munnecke, 2010; Jeppsson et al., 2012). The formation follows the onset of the Lau Event (Jeppsson et al., 2006; Eriksson \& Calner, 2008; Jarochowska et al., 2020a), which is one of several episodes to be coupled with major faunal turnovers and extinctions (Jeppsson, 1987; Koren, 1987; Kaljo \& Märss, 1991; Eriksson et al., 2009) and changes in eustatic sea level (Loydell, 2007; Eriksson \& Calner, 2008; Kozłowski \& Munnecke, 2010). The same event was identified based on fossil fish by Märss (1992), and is subsequently also known as the A. hedei Event. It was later found that these episodes coincided with the most pronounced carbon isotope excursion in the Phanerozoic (Samtleben et al., 1996; Wenzel \& Joachimski, 1996; Bickert et al., 1997; Kaljo et al., 1997; Märss et al., 1998; Wigforss-Lange, 1999; Samtleben et al., 2000; Calner et al., 2008; Jarochowska et al., 2020a; Younes et al., 2017), also recognized on a global scale (see 
Munnecke et al., 2010 and references therein). This Ludfordian Carbon Isotope Excursion (LCIE), also known as the Late Ludfordian CIE (LLCIE) or Middle Ludfordian CIE (MLCIE), reached maximum $\delta^{13} C_{\text {carb }}$ values of $+11 \%$ (Wigforss-Lange, 1999) and permitted highresolution global correlations (Jeppsson et al., 2012). The stratigraphy of the strata placed in the Burgsvik Formation (Fig. 2) holds the key for understanding the sequence of biotic and sea-level changes during this time, but its complex and fragmentary exposures and great lateral variability have hindered comprehensive correlations.

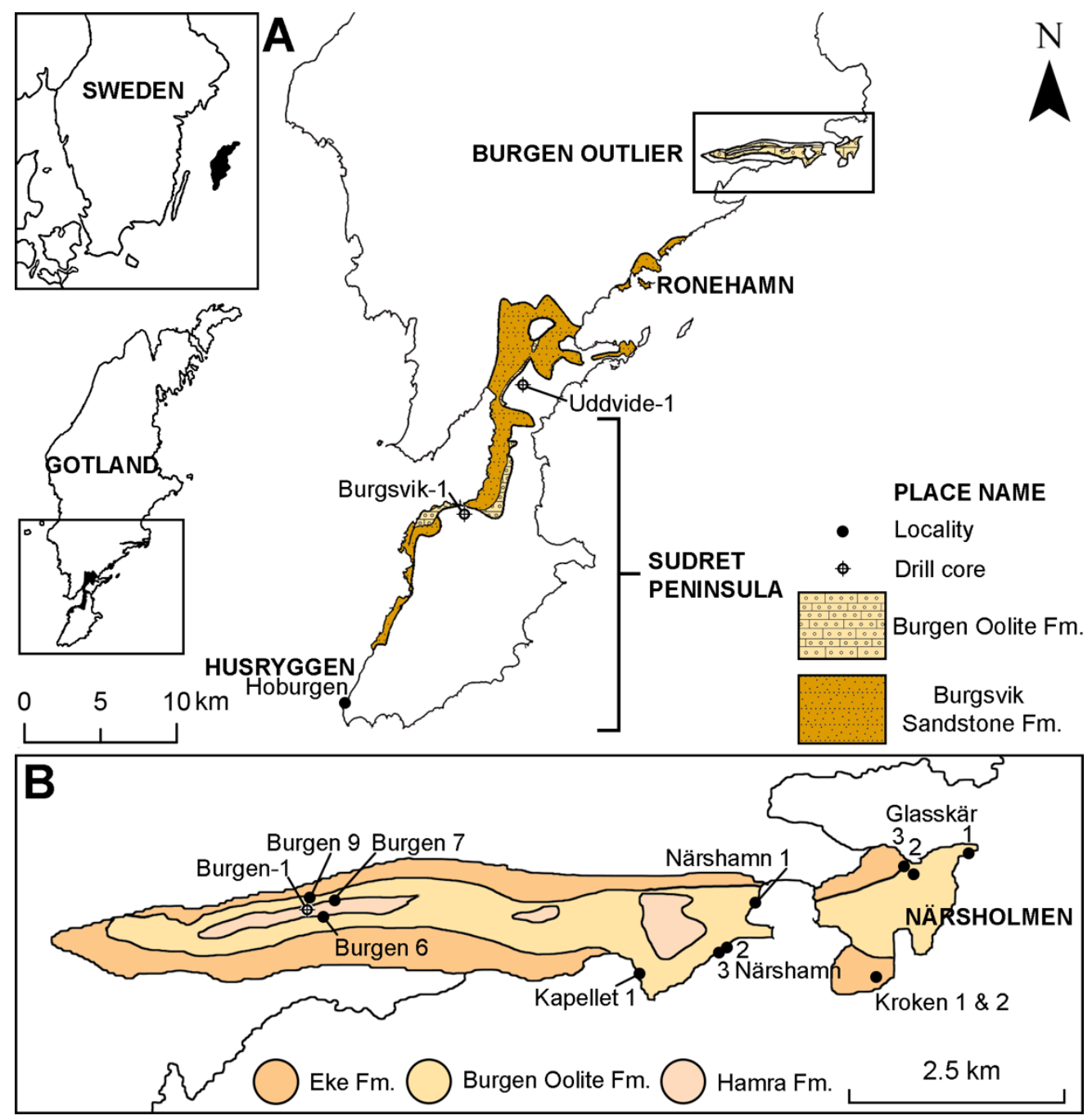

Figure 1. Map of the southern part of Gotland with the Burgsvik Sandstone and Burgen Oolite formations in yellow (A) and a detailed map of the Burgen outlier (B) with Eke Formation in orange, Burgsvik Formation in yellow, and Hamra Formation in light pink. Geographical areas (capital letters), localities, and positions of drillcores that are discussed in the text are also indicated. The geographical extent of the formation and its lithologies are based on Eriksson and Calner (2005) and data from the Geological Survey of Sweden (SGU).

The Burgsvik Formation is exposed along a narrow SW-NE-trending strip in the south of Gotland (Fig. 1): a semi-continuous stretch of outcrops in the western coast of Sudret peninsula and in three small areas in the eastern coast of the island: (1) near Ronehamn, (2) in the Burgen outlier, and (3) in the nearby Närsholmen peninsula (Fig. 1A-B). The strata in 
eastern Gotland represent shoreward facies compared to the westward-lying exposures. On one hand, shallow marine environments may provide diverse fauna and more evidence for sea-level changes in the form of e.g. erosional surfaces, but on the other hand, fauna and carbon isotope values are affected by the facies shifts, making correlations more difficult. This difficulty is particularly relevant to the strata in the Burgen outlier, which have yielded important collections of vertebrate and conodont faunas which could contribute to the understanding of the diversity dynamics during this pivotal time, but which could not be placed biostratigraphically with confidence.

The aim of this study is to document and revise vertebrate and conodont faunas from existing collections housed in the palaeozoological collections of the Swedish Museum of Natural History, Stockholm, and in the Palaeontological collections, Museum of Evolution, Uppsala University. For several samples and localities, the stratigraphic position was not resolved with sufficient precision with respect to recent high-resolution Silurian stratigraphy (Märss \& Männik, 2013; Kaljo et al., 2015; Melchin et al., 2020). In these cases, we revisited outcrops in the Burgen outlier area, identified the depositional environments and reevaluated the age of the Burgsvik Formation in this area with the rest of the formation in Gotland, based on $\delta^{13} C_{\text {carb }}$ chemostratigraphy and biostratigraphy.

\subsection{Lithostratigraphy of the Burgsvik Formation}

The Burgsvik Formation has a maximum thickness of roughly $47 \mathrm{~m}$ in the Burgsvik-1 drillcore (Hede, 1919) and has historically been sub-divided into two units respectively composed of mainly sandstone and oolite (Hede, 1921; Munthe, 1921; Stel \& de Coo, 1977; Long, 1993). These were formally described as the Burgsvik Sandstone Member and Burgsvik Oolite Member by Eriksson and Calner (2008), and are included in the Burgsvik Formation despite being lithologically and genetically distinct and separated by a sequence boundary (Eriksson \& Calner, 2008; Younes et al., 2017). This lithological and genetic difference is addressed here and the two members are elevated to the rank of formations as the Burgsvik Sandstone Formation and the Burgen Oolite Formation. When referring to previous literature reports not differentiating between the two members, we use the 'Burgsvik Formation'. To characterise the Burgen Oolite Formation, we describe the strata exposed in the Burgen outlier and the adjacent Närsholmen peninsula (Fig. 1B). We examine here the depositional position and correlation of these strata with previously described exposures of the Burgen Oolite Formation using the composite section compiled from the 
Uddvide-1 core, Husryggen 4, and Hoburgen in the Sudret peninsula (Fig. 1; Younes et al., 2017).

The Burgen Oolite Formation (formerly: Burgsvik Oolite Member, Fig. 2) is exposed for $15 \mathrm{~km}$ between Hoburgen and Burgsvik along the western coast of Sudret peninsula, unconformably overlying the Burgsvik Sandstone Formation (formerly: Burgsvik Sandstone Member; Eriksson and Calner, 2008). It varies in thickness from several metres to only a few decimetres (Munthe, 1921) and Eriksson and Calner (2008) suspected it to underlie the entire Sudret peninsula based on its occurrence in drillcores. The ooids show great diversity in size and form and are generally sorted into layers according to size (Manten, 1971). On the whole, the member is very heterogeneous and contains shell-lags, sandstones, and locally thin layers of lenticular-bedded mudstones, in addition to the ooid grainstones (Eriksson \& Calner, 2008). The reader is referred to Manten (1971), Calner and Eriksson (2006), and Eriksson and Calner (2008) for detailed lithological descriptions of both formations (as the 'Burgsvik Formation'). 


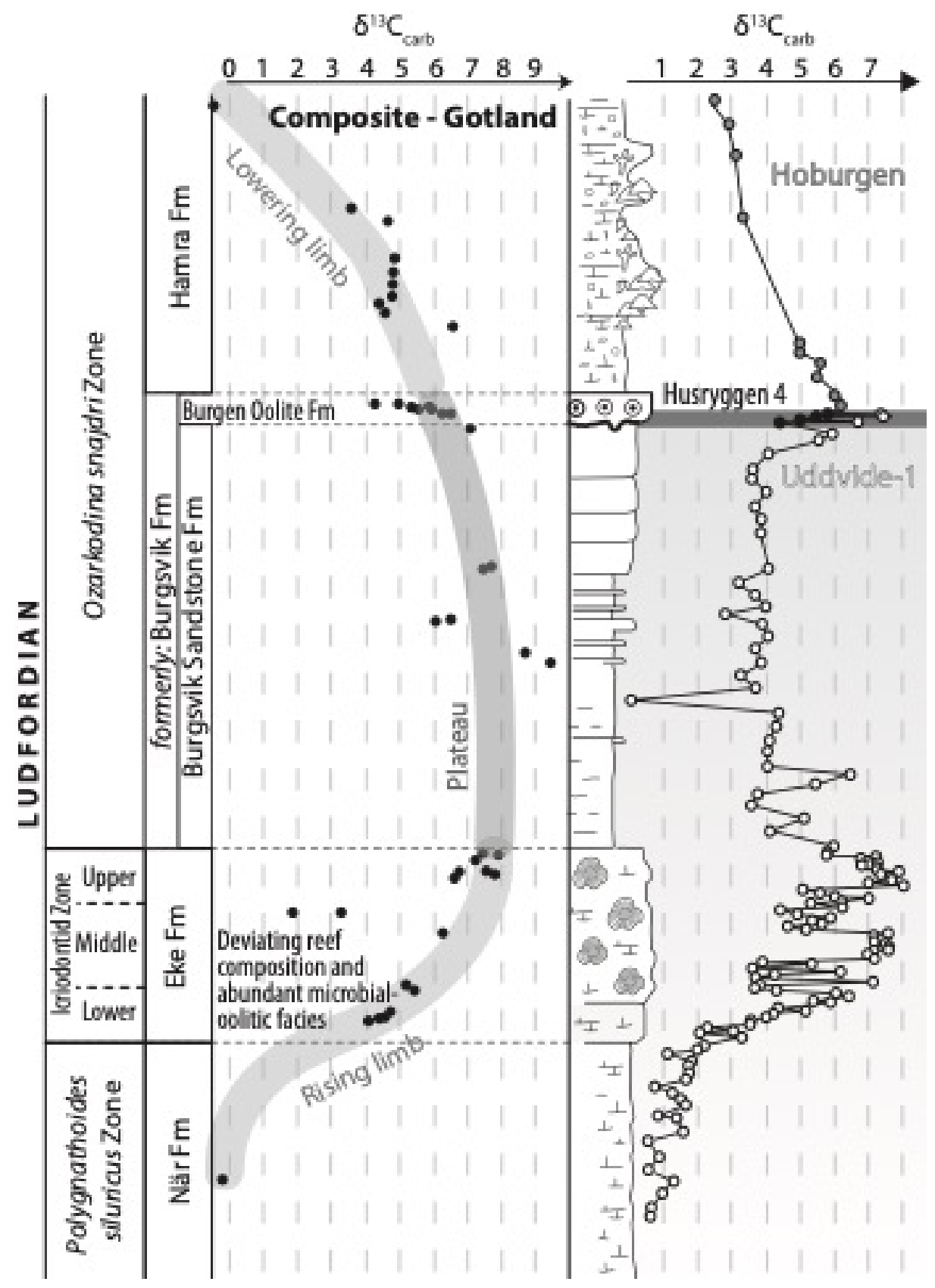

Figure 2. Stratigraphic chart across the LCIE development in Gotland correlated with the composite record of the Uddvide core. The composite $\delta^{13} C_{\text {carb }}$ curve (left) is compiled from Jeppsson et al. (2007) and Samtleben et al. $(1996,2000)$. Conodont biostratigraphy follows Jeppsson (2005) and Jeppsson et al. (2006). The composite profile on the right is from Younes et al. (2017) and was compiled from the Uddvide-1 core (white dots), Husryggen 4 (black dots) and Hoburgen (grey dots).

Traditionally, the 'Burgsvik Formation' was also reported further to the northeast in the Burgen outlier (Munthe et al., 1924, 1925; Manten, 1971), including the Närsholmen peninsula (Fig. 1B; Munthe et al., 1925). These occurrences correspond to the Burgen Oolite Formation, represented by oolites, but there are also local occurrences of marly, timeequivalent reefal limestones according to the studies by Munthe et al. $(1924,1925)$, which are herein included in the formation. These are mainly built up by crinoids, bryozoans, stromatoporoids, and corals (Munthe et al., 1925; Manten, 1971; Larsson, 1975; Stel \& de 
Coo, 1977). Inter-reef deposits are present in both the Burgen and Närsholmen areas and are composed of marly, ruggedly stratified limestones rich in reef-debris such as fragments of crinoids, bryozoans, corals and stromatoporoids (see Manten, 1971). There is a clear difference in the reef and the inter-reef limestones between the Burgen and Närsholmen areas, where the latter seem to have formed in slightly deeper water according to Manten (1971). He described the Närsholmen reefs as forming entirely during 'Burgsvik time', whereas the Burgen reefs continued growing during the deposition of the overlying Hamra Formation.

The wording of Manten (1971) reflects the history of research about Gotland stratigraphy and the basic works by Johan Ernhold Hede during the 1920s to 1940s (summarized in Hede, 1960) that established 13 topostratigraphical units referred to as 'beds' on Gotland. This division heavily influenced later studies (see also Erlström et al., 2009), which is evident in the biostratigraphical subdivision presented in Jeppsson et al. (2006). This has led to some discrepancies regarding the nomenclature of sedimentary units, thus the stratigraphic position of strata in the Burgen and Närsholmen areas has varied between studies. Calner and Eriksson (2006) identified typical lithologies corresponding to the Eke Formation, the Burgen Oolite Formation, and the Hamra Formation in the Burgen-1 drillcore. However, in terms of carbon isotope composition, the 'Burgsvik Formation' in the Burgen-1 drillcore records a steady increase of $\delta^{13} C_{\text {carb }}$ values (Calner \& Eriksson, 2006), a trend that is elsewhere on Gotland observed within the Eke Formation (Samtleben et al., 2000; Jeppsson et al., 2007; Younes et al., 2017). A revised stratigraphy was proposed by Eriksson and Calner (2008), who correlated the entire upper part of the Burgen outlier with the Eke Formation and excluded the 'Burgsvik' and Hamra formations from it entirely. Samtleben et al. (2000) had reached a similar conclusion and excluded the Hamra Formation from the Burgen area. Eriksson and Calner (2008) correlated the clastic-rich interval in the Burgen-1 core with the lower part of Eke Formation in other areas. However, Kozłowski and Munnecke (2010) interpreted the same interval to be coeval with the middle part of the Eke Formation based on the similar increase in isotope values. A recent, continuous $\delta^{13} C_{\text {carb }}$ curve across the LCIE in the Uddvide-1 core (Younes, 2012), Husryggen 4 and Hoburgen (Younes et al., 2017) confirmed elevated values throughout the Burgsvik Sandstone and Burgen Oolite formations and a decline first in the lower part of the Hamra Formation. The difficulties in correlating the Burgen-1 core with the southern part of the island exemplify the lateral variability of the 'Burgsvik Formation'. In the Burgen-1 core, the clastic-rich interval corresponding to the Burgsvik Sandstone Formation is unusually thin (compare 
with fig. 5 in Eriksson \& Calner, 2008) and carbonate-rich. It also shows higher $\delta^{13} C_{\text {carb }}$ values than the typical sandstone facies. Based on correlation with the new composite section in Uddvide-1, Younes et al. (2017) attributed this difference to slight diagenetic overprint in the sandstone facies.

\subsection{Previous biostratigraphic constraints on the age of strata exposed in the Burgen outlier}

The age of the strata in the Burgen and Närsholmen areas has been constrained by conodont biostratigraphy (Jeppsson, 1983, 2005). In fact, the majority of conodonts used to place the Burgen Oolite Formation within the biostratigraphy come from this area (Jeppsson, 2005). The formation is placed in the Ozarkodina snajdri Zone (Jeppsson, 2005; Jeppsson et al., 2006) based on the appearance of the zonal species in the lower part of the unit. Oz. snajdri belongs to a morphologically variable group of $\mathrm{Oz}$. bohemica and has been reported from strata as old as Wenlock (Jeppsson, 1983; Jarochowska et al., 2016), suggesting that it may not be a very sensitive index species (see also Märss \& Männik, 2013). In addition to Oz. snajdri, Jeppsson and Aldridge (2000) reported the following taxa from the 'Ozarkodina steinhornensis' group in what they referred to as the Burgsvik Beds: Oz. scanica in its older part and 'Oz. remscheidensis n. ss. $b^{\prime}$ in the younger one. These taxa have been the subject of intensive taxonomic and stratigraphic revisions since 2000 (Murphy et al., 2004; Carls et al., 2007; Corradini \& Corriga, 2012), so that the original identifications by Jeppsson and Aldridge (2000), which lack illustrations, cannot be compared with currently employed diagnoses and, therefore, zonations. A later revision of the Gotland zonation by Jeppsson et al. (2006) suggested the occurrence of 'Oz. remscheidensis' in the upper part of the Hamra Formation only. Additionally, according to Jeppsson (2005), other taxa appearing first in this formation include Oulodus n. sp. aff. elegans, Ou. elegans, and Ctenognathodus confluens Jeppsson, 1972.

\subsection{Previous reports on the vertebrate fauna in the Burgen outlier}

Spjeldnaes (1950); Fredholm (1989); Märss (1992, 2001); Blom et al. (2002) and Eriksson et al. (2009) only gave infrequent reports of fossil agnathans and gnathostomes from the 'Burgsvik Formation'. Most of these reports correspond to the Burgen Oolite Formation, which displays one of the highest diversity of dermal vertebrate remains in the Gotland sequence, as summarized in Bremer and Blom (2015). Fredholm (1989) dissolved large quantities of rock material from the Burgen Oolite Formation of the Burgen outlier (Fig. 1B). Two samples from localities Burgen 6 and 7 collectively contained a few Thelodus sp. and Loganellia sp. 
Jarochowska et al., Revision of thelodonts, acanthodians, conodonts...

scales. Samples from the Glasskär 1 locality were particularly rich in remains that were dominated by thelodonts Thelodus parvidens Agassiz 1839, Th. sculptilis Gross, 1967, 'Loganellia cuneata' Gross, 1947, Paralogania ludlowiensis Gross, 1967, and Lanarkia? sp. Traquair, 1898, but also contained a subordinate number of acanthodians that she identified as Gomphonchus sandelensis Pander, 1856, Nostolepis striata Pander, 1856, and Poracanthodes porosus Brotzen, 1934 (Fredholm, 1989). A sample from the nearby locality Glasskär 3 contained two Th. parvidens scales, a trilobatiform thelodont scale, one G. sandelensis scale, and some unidentifiable fish remains. Another sample from the Burgen outlier (Kroken 1) showed a similar acanthodian composition as Glasskär 1, but lacked thelodonts Th. parvidens, Th. sculptilis, and Lanarkia? sp., while a sample from Kroken 2 only contained one Loganellia sp. scale. Samples from localities Närshamn 1-3 mainly contained thelodonts referred to as Log. cuneata?, Loganellia sp., and Th. parvidens, a few acanthodian scales identified as N. striata and G. sandelensis, as well as a single fragment of an unidentified osteostracan (Fredholm, 1989). Fredholm (1989) also described one sample from Kapelludden 1 (=Kapellet 1) that produced scales of Th. parvidens, Log. cuneata, and N. striata. Three samples from the Burgen Oolite Formation were treated in Nilsson (2005) and the results were later summarized in Eriksson et al. (2009). Two of them came from the Burgen area, namely Burgen 7 and 9, and collectively contained remains of Th. parvidens, Thelodus sp., P. ludlowiensis, Paralogania? sp., N. striata, G. sandelensis, and Por. porosus. The previous reports of Log. cuneata from Burgen outlier localities Glasskär 1, Kapellet 1, Kroken 1, and Närshamn 1 by Fredholm (1989) were revised as Paralogania? sp. (see Nilsson, 2005 for discussion). We would argue that the scales found and figured as Paralogania? sp. by Nilsson (2005, fig. 13g-i), although eroded, fit within the scale-set presented for P. ludlowiensis (compare Miller and Märss, 1999, plate 2: figs. 16, 21, plate 3: fig. 25). However, Nilsson (2005) also included forms lacking lateral thornlets in this revision, and the previous exclusion of Log. cuneata from the Burgen outlier is further complicated by findings of typical Log. cuneata scales in the Burgen 9 sample presented in this work. Institutional abbreviations - NRM-PZ, Naturhistoriska riksmuseet, PalaeoZoological Collections, Stockholm, Sweden; PMU, Palaeontological collections, Museum of Evolution, Uppsala University, Uppsala, Sweden. 


\section{Material and Methods}

\subsection{Field sampling and new material}

To place previous collections from the Burgen outlier in a palaeoenvironmental and stratigraphic context, we produced lithological sections of the outcrops Burgen 7 (N $57^{\circ} 13^{\prime}$ 47.4", E $\left.18^{\circ} 34^{\prime} 52.6^{\prime \prime}\right)$ and Burgen 9 (N 57 13' 48.4", E 18 34' 36.6") in September 2017 (Figs 1, 3-4). Samples representative of lithologies in both outcrops were used to make thin sections: three from Burgen 7 (Fig. 5) and four from Burgen 9 (Fig. 6). High-resolution scans of thin sections are provided as supplementary data in Jarochowska et al. (2020b).

The Kapellet 1 locality near the bay Närshamn (RT90 6347452, 1671319; N 57² 13' 15.7", E $18^{\circ} 38^{\prime} 29.7^{\prime \prime}$, Fig. 1) has been examined and sampled. No lithological log was produced as the exposure includes a few square metres of nearly horizontal bedding planes, but the bedding planes were cleaned up and are documented here (Fig. 7A). A slide for micro-facies analysis was prepared from a small lithological sample (PMU 23104, Fig. 7C) corresponding to the microfossil sample G14-26-OB, which was also analysed for $\delta^{13} \mathrm{C}$ and $\delta^{18} \mathrm{O}$ values. All thin sections were photographed using Zeiss Axio Zoom V16 binocular microscope with an Axiocam 506 camera and are stored at PMU.

\subsection{Isotope analyses}

For carbon isotope analysis 25 samples were taken in Burgen 9 (Fig. 4) and one at Kapellet 1, directly from sample G14-26-OB (Fig. 7C). Freshly cut surfaces were powdered using a hand drill. Carbonate powders were processed at GeoZentrum Nordbayern by reacting with 100\% phosphoric acid at $70^{\circ} \mathrm{C}$ using a Gasbench II connected to a ThermoFisher Delta V Plus mass spectrometer. All values are reported in per mil relative to V-PDB. Reproducibility and accuracy was monitored by replicate analysis of laboratory standards calibrated by assigning $\delta^{13} \mathrm{C}$ values of $+1.95 \%$ o to NBS19 and $-47.3 \%$ o to IAEA-CO9 and $\delta^{18} \mathrm{O}$ values of $2.20 \%$ to NBS19 and $-23.2 \%$ o to NBS18. Reproducibility for $\delta^{13} \mathrm{C}$ and $\delta^{18} \mathrm{O}$ was \pm 0.02 and \pm 0.03 , respectively. Values are presented in Tab. S2 in Jarochowska et al. (2020b).

\subsection{Fish data}

Numerous samples with undescribed fish remains were found in Jeppsson's (1940-2015) Gotland collection housed at NRM. Three of these derive from Burgen outlier localities, namely Burgen 9 (G94-30 LJ and G94-31 LJ) and Närshamn 2 (G82-12LJ), and they are described here for the first time. Another sample (G14-26-OB) was collected at Kapellet 1 in 
September 2014 and weighted 9.3 kilograms. The sample was dissolved at the Department of Geology, Lund University using techniques described by Jeppsson and Anehus (1995) and Jeppsson (2005). The residues were then separated using the heavy liquid separation technique described by Schiøler (1989). Scanning electron microscopy (SEM) of microremains coated in a gold-palladium alloy was performed at the Evolutionary Biology Centre, Uppsala University with a Zeiss Supra 35VP. Selected specimens are shown in Fig. 8.

\subsection{Conodont data}

Lennart Jeppsson's Gotland conodont collection housed at NRM has been catalogued using his original identifications (where provided) and revised taxonomic names proposed here. The sample position information is assembled from published articles, his handwritten notes hosted at NRM, and his unpublished locality catalogue. All this information has been deposited in the Paleobiology Database (www.paleodb.org). Selected specimens were photographed using a Zeiss Axio Zoom V16 with an Axiocam 506 camera. Examples of relevant taxa are shown in Fig. 9. The figured specimens of both conodonts and fish remains are stored at the NRM (samples starting with Co and C) and PMU.

\section{Results}

\subsection{Facies and depositional environments}

\subsubsection{Burgen 7}

The Burgen 7 locality is a face of a disused quarry exposing ca. $1.7 \mathrm{~m}$ of the Burgen Oolite Formation (Figs 3, 5). The base consists of a $0.4 \mathrm{~m}$ thick bed of grainstone with centimetrescale undulating bedding. The grainstone consists of moderately sorted ooids and an admixture of oncoids (sample AY 2, Fig. 5E-F). The ooid nuclei are represented by a range of fossils, including crinoid ossicles, bryozoans, brachiopods, ostracods, fragments of tabulate corals and thelodont scales. Most ooids occur in initial stages, with only two-three layers present (Fig. 5F). The ooid grainstone is followed by $1.2 \mathrm{~m}$ of similarly bedded oncoidal rudstone (sample AY 7, Fig. 5B). The beds in the rudstone are between 4 and $8 \mathrm{~cm}$ thick and show trough (festoon) cross stratification. The beds in the topmost $15 \mathrm{~cm}$ of the rudstone are thinner $(<4 \mathrm{~cm})$ and contain single large components. A thin section taken from this topmost part revealed very poorly sorted initial oncoids (Fig. 5C) formed around crinoid ossicles, fragments of the tabulate coral Coenites, brachiopods, recrystallised mollusc shells, lithoclasts, or aggregations of calcareous microproblematica (Fig. 5D). Some oncoid nuclei 
appear to have undergone lithification, partial dissolution or mechanical destruction and filling with cement or intensive abrasion. The matrix is spotted, with areas formed by clotted peloidal micrite and areas filled with sparitic cement. The top of the outcrop is formed by grainstone transitioning to massive framestone. The thin section through the grainstone revealed bimodal sorting: the fine fraction consists of peloids and highly fragmented skeletal grains dominated by ostracod shells, the coarse fraction consists of complete, in some cases articulated, brachiopod shells and crinoid ossicles (sample AY 8, Fig. 5A).

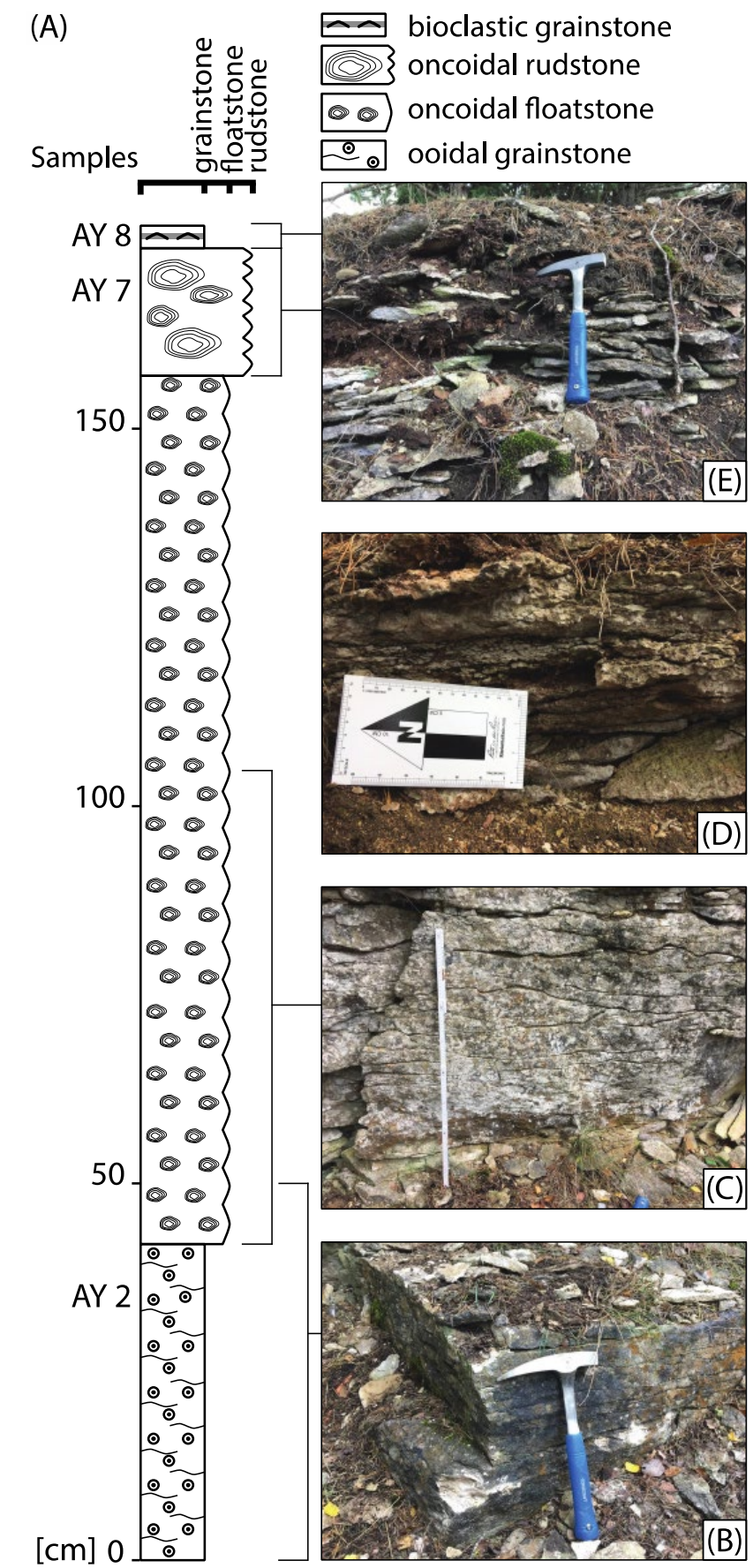

Figure 3. The Burgen 7 section across the Ludfordian Burgen Oolite Formation in the Burgen outlier in eastern Gotland. AY2, 7-8 refer to thin section samples (Fig. 5). 


\subsubsection{Burgen 9}

This outcrop is a disused quarry, which has been extensively cleaned for the needs of this study (Fig. 4). The $23 \mathrm{~m}$-long northern wall of the quarry has been logged along with the adjacent $6 \mathrm{~m}$-long western corner. The strata show great lateral variability along this short distance. The floor consists of large, level bedding planes of well-sorted coarse crinoidal rudstone with decimetre-scale beds and low-angle cross stratification. The thickness from the lowest exposed level reaches up to $2 \mathrm{~m}$, but the top of this unit is undulating. The transition from the coarse crinoidal rudstone to the more brittle and thinner bedded oolite, forming most of the quarry walls, is a layer of bioclastic-ooidal grainstone-rudstone with bimodal sorting (sample AY 10, Fig. 6A). The larger size fraction in this transitional layer consists of crinoid ossicles, brachiopod and trilobite shells and initial oncoids, whereas the smaller fraction consists of ooids and ostracod shells. The proportion of microbial structures increases here and small patches of bindstones intercalate directly with the grainstonerudstone beds (sample AY 11, Fig. 6B-C). The bindstone is formed by macroscopic patches of Rothpletzella with small stromatoporoids and spongiostromate oncoids (Fig. 6C). The intercalating fauna is poorly sorted and diverse, including crinoids, rhynchonellid and strophomenid brachiopods, ostracods, trilobites and rostroconchs (Fig. 6C). The overlying oolite is thin bedded, with normal grading in the eastern part of the quarry (sample AY 14, Fig. 6D-E) and small-scale trough (festoon) cross stratification in the central part. The ooids are radial and consist only of a few layers, with bioclasts in their cores recognizable as echinoderm ossicles, brachiopod and recrystallized shells or fragments of microbial structures. Centimetre-scale normal grading is formed by repeated influx of coarse crinoid ossicles and is enhanced by stylolites. 

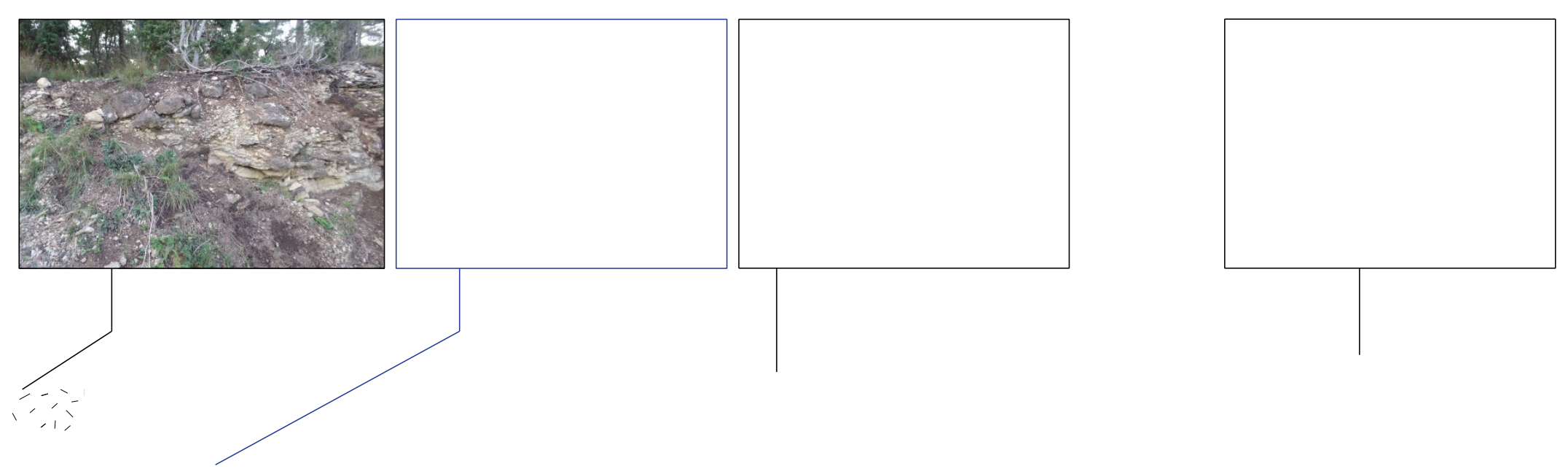

Figure 4. Lateral sketch of the Ludfordian Burgen Oolite Formation at Burgen 9 in the Burgen outlier in eastern Gotland. Red numbers along the vertical transect correspond to isotope samples in Fig. 10 and blue numbers correspond to thin section samples (Fig. 6). The section exposes lateral transition between metazoan reefs and oolites, overlying well-sorted crinoidal grainstones, which form the base of the former quarry (condition in 2017). 
In the northern wall of the quarry, the crinoidal rudstone transitions laterally into metrescale patch reefs (Fig. 4). The reefs have varying compositions, with bryozoans, stromatoporoids and rugose corals present in the westernmost part (only partly exposed) and a crinoid-microbial-bryozoan association exposed in the quarry corner (sample AY 17, Fig. 6F-I). The reefs have sharp margins and partly erosional boundaries (Fig. 6I). The cores are formed by crinoidal-microbial framestone-boundstone, with tabulate corals and serpulids intergrowing within crinoids and encrusting them. The frame-builders are coated with dense filamentous microbial carbonates formed by Rothpletzella and the matrix is mottled micritic with fenestral structures. The fabric surrounding the sharp margin of the patch reef is a poorly sorted bioclastic rudstone. The components are aligned with the edge of the reef, either by synsedimentary processes or by compaction. The bioclasts include crinoids, diverse brachiopods, bryozoans and tabulate corals, trilobites, spongiostromate oncoids, recrystallized shells with initial porostromate oncoids forming on their surfaces, solenoporaceans, rostroconchs (Fig. 6G) and scattered microbial structures including Ortonella (Fig. $6 \mathrm{H}$ ) and Rothpletzella. The matrix consists of nearly equal proportions of micrite and sparite. 

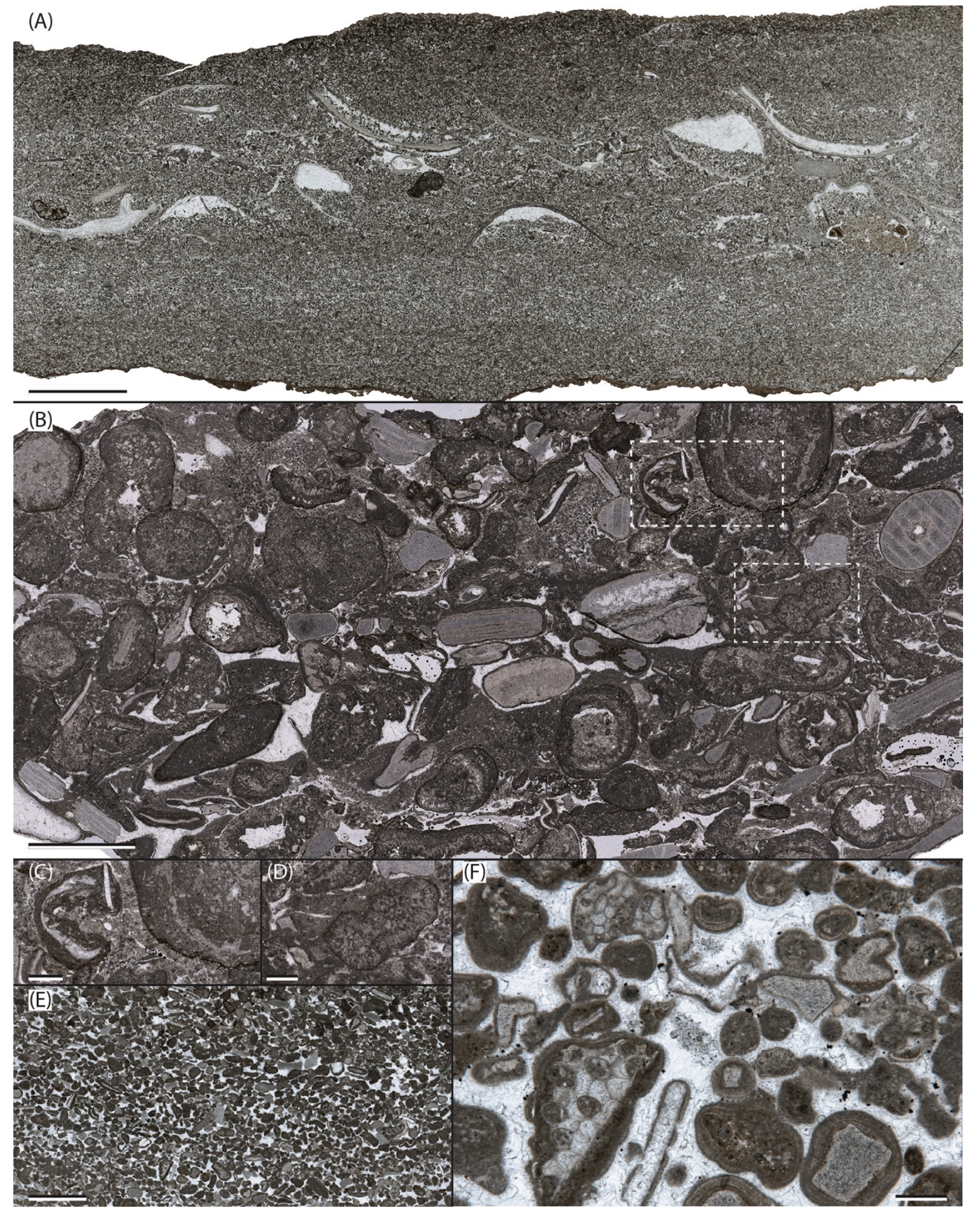

Figure 5. Microfacies at the Burgen 7 section. A. Sample AY 8: peloidal grainstone with a brachiopod shell layer. Scale bar $500 \mu \mathrm{m}$. B-D. Sample AY 7: oncoidal rudstone. Scale bar $500 \mu \mathrm{m}$. B. Scale bar $500 \mu \mathrm{m}$. C-D. Scale bar $100 \mu \mathrm{m}$. E-F. Sample AY 2: ooidal grainstone. E. Scale bar $500 \mu \mathrm{m}$. F. Scale bar $100 \mu \mathrm{m}$. 


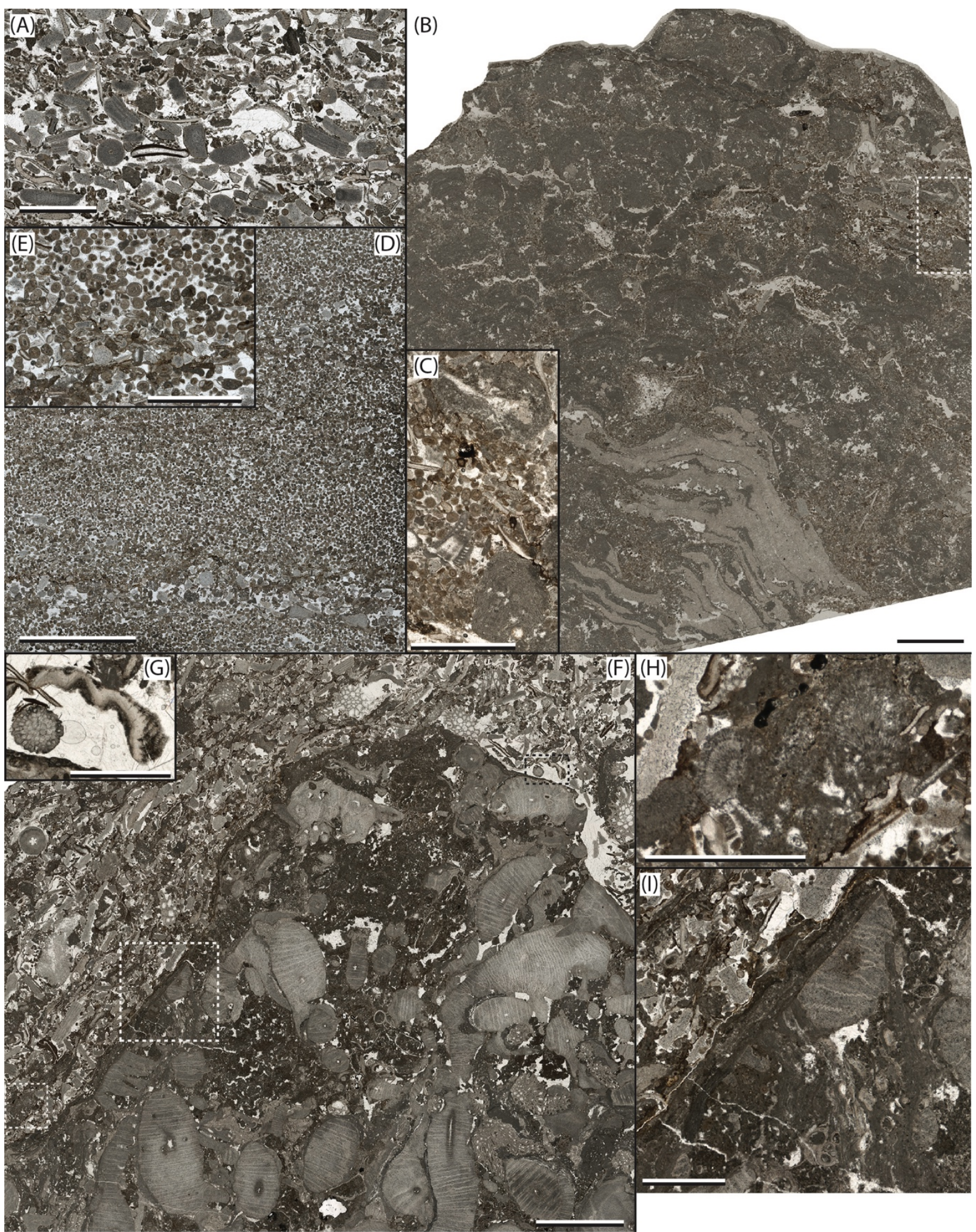

Figure 6. Microfacies at the Burgen 9 section. A. Sample AY 10: bioclastic rudstone with bimodal sorting. Scale bar $250 \mu m$. B-C. Sample AY 11: microbial bindstone intercalating with bioclastic-ooidal grainstone. Scale bar $500 \mu m$. C. Close up of sample AY 11 showing a spongiostromate oncoid, a rostroconch fragment and a Rothpletzella colony. Scale bar $250 \mu \mathrm{m}$. DE. Sample AY 14: ooidal grainstone with normal grading. Scale bar $500 \mu \mathrm{m}$. E. Detail of sample AY 14: fitted fabric partly dissolving echinoderm ossicles, ooids and fragments of microbial structures. Scale bar $250 \mu \mathrm{m}$. F-I. Sample AY 17: contact between crinoidal-microbial boundstone and bioclastic rudstone. Scale bar $500 \mu \mathrm{m}$. G. Probable rostroconch. Scale bar 250 $\mu \mathrm{m}$. H. Problematica resembling Ortonella. Scale bar $250 \mu \mathrm{m}$. I. Erosional contact truncating crinoid roots intertwined with microbial structures. The contact surface is overgrown by another generation of microbial colonies dominated by Rothpletzella. Scale bar $250 \mu \mathrm{m}$. 


\subsubsection{Kapellet 1}

This is a coastal outcrop consisting of a strip of bedding planes gently dipping towards the West (Fig. 7A). It was placed in the 'Burgsvik Formation' based on conodont fauna, which was assigned by Jeppsson et al. (2006) to the lowermost part of the Oz. snajdri Biozone ("Oz. scanica without Oz. (Wurmiella) excavata"). Within the small Kapellet 1 outcrop a full transition from a slightly calcareous sandy siltstone to a bioclastic-oncoidal rudstone is exposed (Fig. 7B-C). The rudstone consists of very coarse, partly still articulated crinoid stems, large disarticulated trilobite, brachiopod and recrystallized bivalve shells, as well as colonies of bryozoans and tabulate and rugose corals, which are ex situ but not fragmented. Most grains are initial-stage oncoids, with spongiostromate fabrics dominating. The matrix consists of similar proportions of sparite forming fenestral structures and clotted, peloidal micrite (Fig. 7C). Below this layer, large $(2-3 \mathrm{~cm})$ mature spongiostromate oncoids are the dominant components, with a bioclastic packstone-rudstone as a matrix. The sandy, calcareous siltstone is thin-bedded and intercalates between the components of the rudstone. Scattered bioclasts can be found on its bedding planes. At the scale of the outcrop, the siltstone appears to be overlying the rudstone or filling shallow troughs in its uneven surface, but outcrop size and conditions did not allow establishing larger-scale relationships between these two units. 


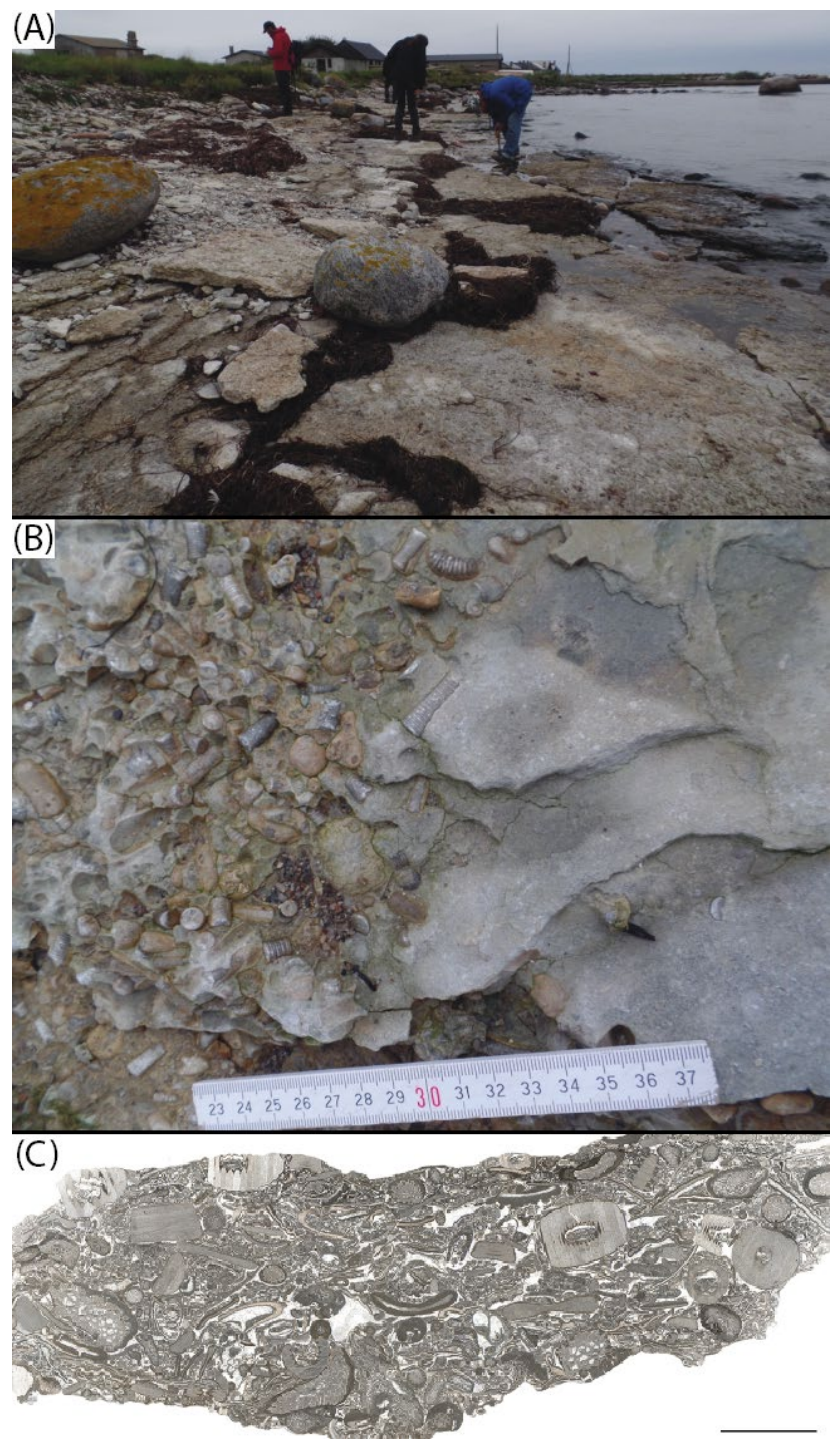

Figure 7. The Burgen Oolite Formation at the Kapellet 1 section. A. Outcrop overview in 2017. B. Intercalation of carbonate-rich sandy siltstone with crinoidal-rudstone corresponding to the boundary between the Burgsvik Sandstone and Burgen Oolite formations. C. Microfacies slide (PMU 23104) showing oncoids forming around partly articulated crinoids, bryozoans, trilobites, and brachiopods in a micritic matrix with fenestral structures.

\subsection{Dermal vertebrate remains of the Burgen Oolite Formation in the Burgen outlier}

The sample from the Närshamn 2 locality (G82-12LJ) contains 28 P. ludlowiensis scales of several different morphologies, many of which preserve parts of the extremely fine lateral extensions (Fig. 8A) and some, as in Figure 8B, display fin scale morphologies (compare Miller \& Märss, 1999: pl. 2, fig. 25). There are also eight thelodont scales of unclear affinity that have three-pointed crowns and small anterior spurs (Fig. 8C). One additional scale has a Th. traquairi-like morphology (Fig. 8D), but is quite large and laterally compressed with an oval, low base that hosts a relatively large pulp opening. The crown is vertically steep and high, and it has a number of ridges that converge and end in a single central point. This probably represents a special scale in the squamation of a thelodont, potentially Th. 
parvidens. Peculiarly, there are no other scales of Th. parvidens in this sample, which is odd because this taxon is found in both older and younger strata on Gotland (and all other samples presented here), and occurs in a wide range of depositional environments (see Kaljo et al., 2015). A single Thelodus trilobatus Hoppe, 1931 scale (Fig. 8E) has been identified in the sample and only one acanthodian scale was found, but it was too poorly preserved for identification.

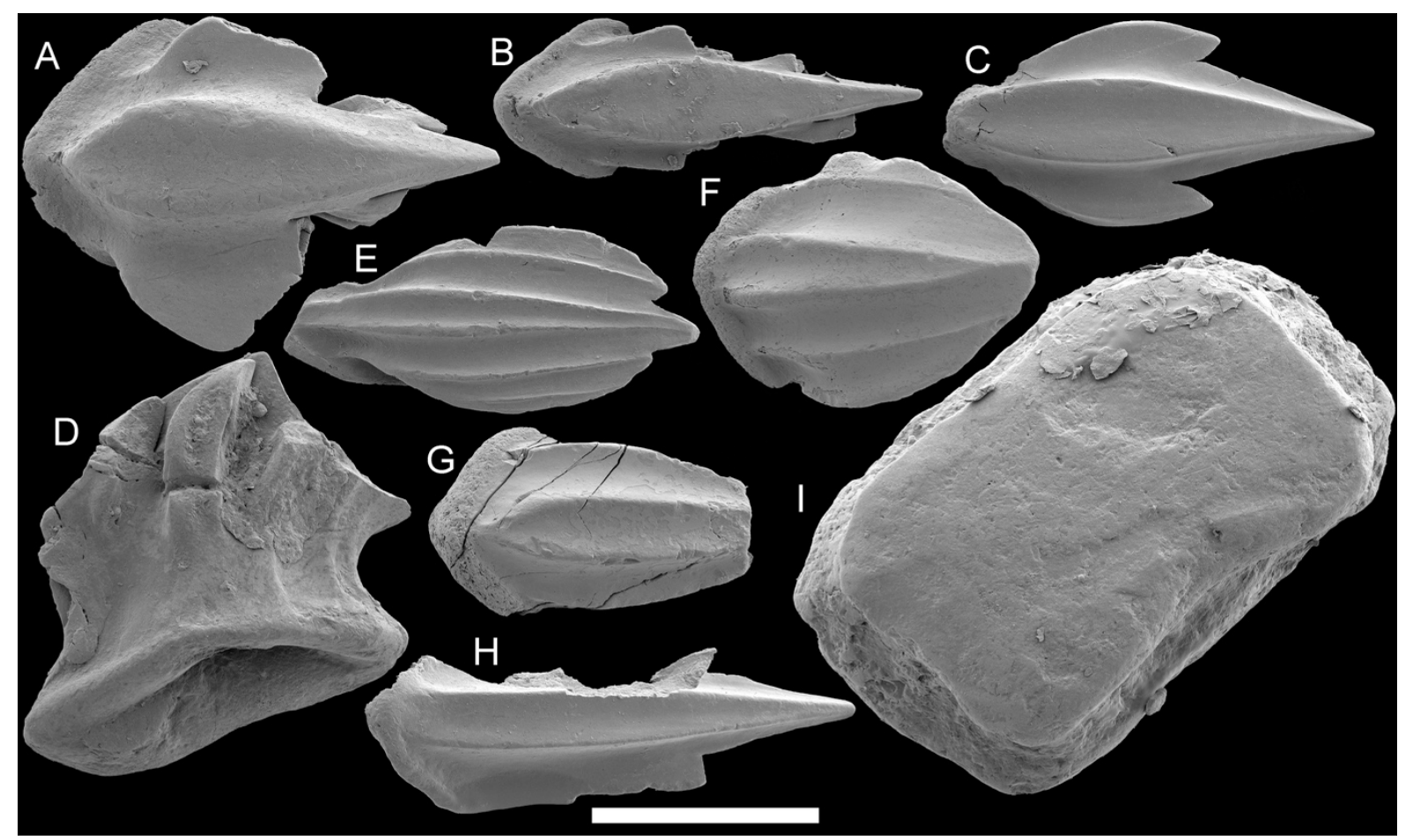

Figure 8. Thelodont and acanthodian scales from Burgen outlier. Paralogania ludlowiensis (A-B, NRM-PZ C6011-6012), three-pointed thelodont scale (C, NRM-PZ C6013), traquairiform scale (D, NRM-PZ C6014), and Thelodus trilobatus (E, NRM-PZ C6015) from Närshamn 2 (G82-12LJ). Loganellia cuneata (F-G, NRM-PZ C6009-6010) from Burgen 9 (G9430LJ). Three-pointed thelodont scale (H, PMU 24034) and Gomphonchus sp. (I, PMU 24035) from Kapellet 1 (G1426OB). Scale bar represents $200 \mu \mathrm{m}$.

The two samples G94-30 LJ and G94-31 LJ from the Burgen 9 locality from L. Jeppsson's collection contain 20 scales of typical Th. parvidens morphologies similar to those presented by Eriksson et al. (2009: fig. 4D), 25 P. ludlowiensis scales, five scales with affinities to $N$. striata, and a couple of acanthodian tesserae collectively. G94-30 LJ also contains two leaflike scales (Fig. 8F) resembling the transitional? scales presented for Log. cuneata in Märss and Miller (2004: fig. 6c), as well as a few typical Log. cuneata trunk scales (Fig. 8G). The faunas in these samples are similar to those described by Nilsson (2005) from Burgen 9, but lack the poracanthodid scales (described as Por. porosus), and in addition have climatiid scales and scales identified as Log. cuneata.

The new sample from the Kapellet 1 locality (G14-26OB) only produced a few remains and the fauna is similar to that presented in Fredholm (1989) from the same locality. 
The sample contains five Th. parvidens trunk scales and two three-pointed thelodont scales with a small anterior spur on the base (Fig $8 \mathrm{H}$ ) similar to those found in the G82-12LJ sample described above. The sample also contained three small scales of $N$. striata and three G. sandelensis scales. Another scale has a rhomboidal outline, flat crown and deep base (Fig 8I) and is interpreted as a special 'gomphonchid' scale and referred to Gomphonchus sp.

\subsection{Conodonts of the Burgen Oolite Formation in the Burgen outlier}

Jeppsson's unpublished catalogue of localities on Gotland lists over seventy localities and three drillcores where the 'Burgsvik Formation' is accessible. However, only a fraction of these localities expose the Burgen Oolite Formation and a subset of those is represented in the conodont collection (Table 1, Fig. 9). The conodont fauna from the Burgen Oolite Formation in the Burgen outlier is more diverse than that reported from the Sudret peninsula. Young, not fully developed ozarkodinins in samples from 1994 (G94-29 LJ from Burgen 7 and G94-30 LJ from Burgen 9) were assigned by Jeppsson to 'Oz. remscheidensis' Ziegler, 1960, as indicated by labels on the microslides. Later articles by Jeppsson did not mention this taxon in this area, reporting the presence of Oz. scanica instead (Jeppsson, 2005; Jeppsson et al., 2006). These specimens are here revised as 'Oz.' eosteinhornensis 'scanica', but a thorough revision of the morphological variability across ontogeny would be warranted to support this revision (see Discussion). Sample G83-21LJ from Burgen 7 was reported by Jeppsson (2005) to contain Aldridgeodus minimus? Jeppsson in Calner et al. (2008), a species otherwise known from strata no younger than the Polygnathoides siluricus Biozone (on Gotland corresponding to the uppermost Hemse Group), and Panderodus serratus Rexroad, 1968, which occurs in the Eke and Hamra formations, but has otherwise not been known from the Burgsvik Sandstone or the Burgen Oolite formations. Resampling of the same level did not confirm the presence of these taxa, therefore Jeppsson (2005) suggested treating these findings as erroneous. Panderodus greenlandensis Armstrong, 1990 was found in a single sample G94-32 LJ from Burgen 9, at the stratigraphically youngest position ever reported. A specimen from Glasskär 2 (G72-19LJ) labeled by Jeppsson as Ozarkodina wimani (Jeppsson, 1974) is herein identified as Zieglerodina inordinata (Viira, 2000) based on the wide gaps between the cusp and adjacent denticles (Fig. 8L). This species was described from the Přídolí of Estonia and Latvia by Viira (2000) as Oz. inordinata, but the generic assignment has been queried by Murphy et al. (2004). Subsequent works placed the species in Zieglerodina based on the morphology of the $\mathrm{P}_{1}$ element and the similarity to Z. ivochlupaci (Peavey, 2013; Spiridonov et al., 2020b). 


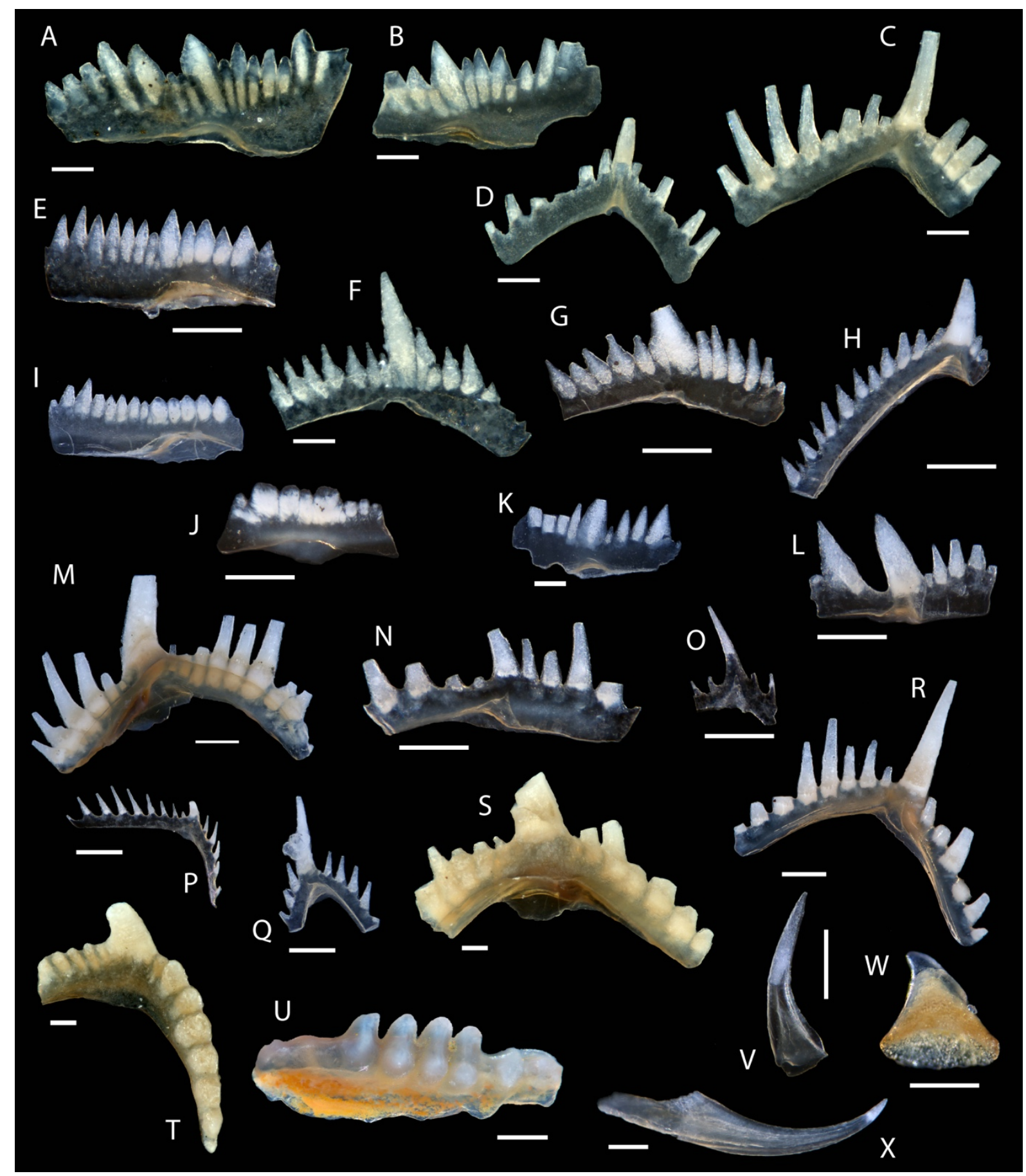

Figure 9. Conodonts from the Burgen Oolite Formation in the Burgen outlier and Närsholmen peninsula. L. Jeppsson's collection and newly collected from Kapellet 1. Ozarkodina confluens Branson and Mehl, 1933 from Kapellet 1 (A-B, PMU 23109-23110, C, Co210, D, PMU 23107). 'Oz.' eosteinhornensis scanica (Oz. scanica in the original identification) Jeppsson, 1974 from Närshamn 1 (G83-11LJ; E, Co66, H, Co67) and Närshamn 2 (G83-12LJ; G, Co69). ‘Oz. eosteinhornensis? (F, PMU 23108) from Kapellet 1 (G14-26OB). Ozarkodina snajdri Walliser, 1964 from Närshamn 2 (I, Co68, G83-12LJ) and Glasskär 2 (J, Co63, G72-19LJ). Oz. wimani Jeppsson, 1974 from Glasskär 2 (G72-19LJ; K, Co64). Zieglerodina inordinata (Viira, 2000) from Glasskär 2 (G72-19LJ, L, Co65). Ou. novoexcavatus Jeppsson, 1972 (M, Co0000075, N, Co76, O, Co74, P, Co77, Q, Co73) from Närshamn 1 (G83-11LJ) and from Närshamn 2 (R, Co71, G8312LJ). Ou. excavatus Branson and Mehl, 1933 from Kapellet 1 (S-T, PMU 23105-23106). Icriodus sp. (U, Co174) from Burgen 9 (G94-31LJ). Decoriconus fragilis Branson and Mehl, 1933 (V, Co78) from Närshamn 1 (G83-11LJ).

Pseudooneotodus beckmanni Bischoff and Sannemann, 1958 (W, Co79) from Närshamn 1 (G83-11LJ). Panderodus equicostatus Rhodes, 1953 (X, Co72) from Närshamn 2 (G83-12LJ). All scale bars equal $100 \mu \mathrm{m}$. 
Table 1 also lists conodonts identified at Glasskär, Kroken and Närshamn, most of them were probably collected in the Burgen Oolite Formation. 'Oz.' eosteinhornensis was represented by both forms referred to by L. Jeppsson as 'scanica' (Fig. 9E, H, G) and 'non scanica'.

The Kapellet 1 locality, recorded in the collection under the name Kapelludden 1, has been included by L. Jeppsson in the 'Burgsvik Formation' based on the presence of $\mathrm{Oz}$. wimani (Table 1), although the exposed strata differ from the typical lithology and the conodonts he collected there were not diagnostic. The newly collected sample from Kapellet 1 (G14-26-OB) contained a possible $\mathrm{P}_{2}$ element of 'Oz.' eosteinhornensis (Fig. 9F).

\subsection{Isotope chemostratigraphy}

Carbon isotope values at Burgen show steady values ranging between $+8.8 \%$ and $+9.2 \%$ o ${ }^{13} \mathrm{C}_{\mathrm{carb}}$ in spite of lithological variations (Fig. 10). The oxygen isotopes range between $-5.9 \%$ and $-7.1 \%$ o $\delta^{18} \mathrm{O}_{\text {carb}}$, which does not indicate any extreme diagenetic alteration. The lithological sample from Kapellet 1 shows isotope values of $+7.5 \%{ }^{13} C_{\text {carb }}$ and $-6.9 \%$ o $\delta^{18} \mathrm{O}_{\text {carb }}$. The relationship between $\delta^{13} \mathrm{C}$ and $\delta^{18} \mathrm{O}$ was weak $\left(\mathrm{R}^{2}=0.27\right)$ but significantly different from no relationship ( $p=0.0049, \mathrm{n}=25$ ), suggesting a possible diagenetic overprint (Fig. S1 in Jarochowska et al., 2020b).

\section{Discussion}

\subsection{Interpretation of depositional environment}

The Burgen 7 and 9 outcrops record a transition from a very high-energy, fully marine shoal setting represented by the well-sorted coarse crinoidal rudstone, exposed in the quarry floor at Burgen 9, to a more patchy, topographically complex environment with intercalation of patch reefs, ooid shoals and oncolites. Oncolites have been associated with restricted conditions, e.g. in the Eke Formation, but high faunal diversity indicates fully marine conditions and oolitic shoals and metazoan reefs point to an environment above the wave base. The interval exposed at Burgen 7 likely corresponds to the facies exposed in the eastern part of the quarry, where the isotope transect had been sampled (Fig. 4). In both outcrops, oncoids differ from the 'cauliflower' type known from the Eke Formation (Eriksson \& Calner, 2008) and corresponding to type C oncoids of Ratcliffe (1988). Such ooids are commonly interpreted to have grown in situ and are found in low-energy settings with restricted fauna, where their development is attributed to reduced grazing by herbivores 
(Calner, 2005). This is clearly not the case here, as oncoids co-occur with gastropods and a diverse fauna. They also represent type A of Ratcliffe (1988), typical of high-energy settings, and bear traces of transport and abrasion.

\subsection{Conodont biostratigraphy and diversity}

Minimum conodont species richness in the Burgen outlier was estimated at 21 (with four species in open nomenclature and one uncertain identification, Tab. 1). The generic richness reaches 11, although the position of species assigned to Ozarkodina is debated (see 4.6 and 4.7). The high diversity in the outlier might reflect high spatial diversity and patchiness of the back-shoal settings compared with the high-energy open shoal environment of the oolite in the Sudret peninsula (Jarochowska et al., 2017).

The Burgsvik Sandstone and Burgen Oolite formations have been placed in the $\mathrm{Oz}$. snajdri Interval Biozone (Jeppsson et al., 2006). In its original definition by Walliser (1964), the lower limit of this biozone is defined by the Last Appearance Datum (LAD) of Pedavis latialata, a species not reported from Gotland and rejected by Jeppsson (2005) as a useful index taxon. A broader definition of the Oz. snajdri Biozone uses the LAD of Po. siluricus (Aldridge \& Schönlaub, 1989; Corradini \& Serpagli, 1999). Elsewhere a broader definition of the Oz. snajdri Biozone has been adopted (Corradini et al., 2015). The latialata Biozone was proposed by Jeppsson (2005) to be defined on Gotland by the 'extinction' of Polygnathoides and Kockelella and the appearance of more than one species of Icriodus spp. This biozone is termed 'icriodontid' and is, according to Jeppsson et al. (2006), represented on Gotland by the Eke Formation, but the zonal genus Icriodus has been found in only three samples in the entire collection of L. Jeppsson stored at NRM. It is also more widespread in the uppermost Silurian and Lower Devonian (not represented on Gotland), and is therefore a poor choice for an index taxon for the Ludfordian Stage.

The Oz. snajdri Biozone has been redefined on Gotland by Jeppsson (2005) as the interval with high abundance of $\mathrm{Oz}$. snajdri, which he related to the 'extinction' of several other species. Ozarkodina snajdri is common in samples from the Burgen outlier, but it is absent in the Burgen Oolite Formation in the Sudret Peninsula and at Uddvide (Table 1). It is therefore difficult to establish the base of this biozone on Gotland, as the Eke Formation is overall extremely poor in conodonts and effectively lacks distinctive taxa. Moreover, $\mathrm{Oz}$. snajdri morphologies are found as early as in the Oz. bohemica Biozone on Gotland (Jeppsson, 1983, 2005). 
The upper limit of the Oz. snajdri Interval Biozone is defined by the first occurrence of Oz. crispa. However, Oz. crispa has also been found in sample G72-17CB from Glasskär 1 (probably Burgen Oolite Formation). This species is also known from earlier occurrences in the Baltic area (Viira \& Aldridge, 1998; Bremer et al., 2020), although Märss and Männik (2013) suggested that these may represent specific morphologies of Oz. snajdri and considered them Oz. snajdri sensu lato. Jeppsson et al. (2006) assigned only the Sundre Formation to the Oz. crispa Biozone, although the taxon has been identified by L. Jeppsson in samples from the Hamra Formation (Bremer et al., 2020). The Hamra Formation was placed by Jeppsson et al. (2006) in the Oz. snajdri Interval Biozone, which was then subdivided based on the occurrences of 'Oz. scanica' and 'Oz. remscheidensis'. Both these taxa underwent multiple revisions of their taxonomic ranks and diagnoses, resulting in their distribution being difficult to reconstruct from previous reports, unless exhaustive descriptions are provided (see chapter 4.6 below). In any case, the presence of 'Oz.' eosteinhornensis 'scanica', Oz. crispa and Oz. snajdri at Glasskär 1, and of 'Oz.' eosteinhornensis 'scanica' and Oz. snajdri at both Burgen 7 and 9 are the basis for assigning the Burgen Oolite Formation in the Burgen outlier to the Oz. snajdri Biozone sensu Jeppsson et al. (2006) and exclude an older age, which will be further discussed in 4.5. The diagnostic taxa could not be identified at Kapellet 1 , except for a $\mathrm{P}_{2}$ element of 'Oz.' eosteinhornensis 'non scanica'.

The finding of Zi. inordinata at Glasskär 2 extends downwards the range based on rare reports from the Př́dolí of Estonia and Latvia by Viira (2000), of Lithuania by Spiridonov et al. (2020) and of Oklahoma by Peavey (2013). However, as noted by Spiridonov et al. (2020b), the scarcity of reports might reflect a strong affinity of this taxon to very shallow water environments, which saw a diversification in the late Silurian (Einasto \& Viira, 2003; Jarochowska et al., 2017). Accordingly, it has not been found in samples from the more open-marine facies of the Burgen Oolite Formation in the Sudret peninsula.

\subsection{Vertebrate biostratigraphy and diversity}

Thelodus parvidens and its possible scale-variant Th. trilobatus have long stratigraphic ranges and occur in a wide range of lithologies (Kaljo et al., 2015). Paralogania ludlowiensis has also been suggested as having a fairly long temporal range, but has been shown to mainly occur in high-energy, shallow-marine environments often with a clastic input (Kaljo et al., 2015; Bremer et al., 2018; 2020). However, the previous reports of Th. sculptilis (Fredholm, 1989) and poracanthodid acanthodians (Fredholm, 1989; Eriksson et al., 2009) from Burgen outlier indicate a late-, rather than mid-Ludlow age of these samples (see Märss and Männik, 2013). 
Indeed, these taxa are more readily found in younger strata on Gotland (Bremer et al., 2020). Furthermore, the samples from Burgen outlier lack the thelodonts Thelodus carinatus Pander, 1856 and Phlebolepis elegans Pander, 1856 that are typical for faunas found in older strata on Gotland (e.g., Fredholm, 1989; Eriksson et al. 2009). In fact, the latter is an index taxon for the Phlebolepis elegans Vertebrate Zone Märss, 1982 and has a partial range into the mid-Ludlow Andreolepis hedei VZ Märss, 1982 (Märss \& Männik, 2013).

The whereabouts of Doris Fredholm's samples are at the time of writing unknown, so a review of her material has not been possible. For this reason, it remains unclear how the previous revision of all reports of Log. cuneata in the Burgen outlier to Paralogania? sp. by Nilsson (2005) compares to the findings of typical Log. cuneata scales in the samples presented here, especially because Nilsson (2005) included forms both with and without lateral thornlets in her preliminary designation.

Eriksson et al. (2009) described a step-wise disappearance of vertebrate taxa during the Lau Event, starting at the top of the När Formation (Hemse Group) and continuing throughout the Eke Formation on Gotland. They recorded a shift from an acanthodiandominated fauna before the event to a thelodont-dominated fauna in the Burgen Oolite Formation during the initial recovery, which was also noted by Fredholm (1989). The fishes display a post-Lau Event recovery after their overall scarcity in the preceding Eke Formation (Fredholm, 1988a, b; Eriksson et al., 2009; Bremer \& Blom, 2015) with the return or first appearance of several taxa (Märss, 1992, 2001; Eriksson et al., 2009). The samples investigated here similarly show a relatively diverse fauna with a higher abundance of thelodont scales compared to acanthodian remains, but the sampling size is too small to discuss any further implications.

\subsection{Comparison with palynozones}

The Silurian was a significant interval for land plant evolution, a period under which the plants became well-established on most continents, markedly increasing in abundance, and with new and more derived forms appearing (Gray et al., 1974; Richardson \& McGregor, 1986; Wellman et al., 2013; Mehlqvist et al., 2015). This is clearly reflected in the spore assemblages with more ornamented spores appearing in the upper Silurian sedimentary record (Richardson \& McGregor, 1986; Mehlqvist et al., 2015). Combining terrestrial palynology with marine micropalaeontological data provides information on stratigraphy and paleoenvironments, such as distance from shore and level of anoxia (Mehlqvist et al., 2012, 2014b; Badawy et al., 2014). 
The knowledge on the terrestrialization of Baltica is scarce and patchy, with the oldest known records of embryophyte (land plant) spores from the Eoplacognathus lindstroemi conodont subzone of the Furudal Limestone (mid-Ordovician: Darriwillian) of central Sweden (Rubinstein \& Vajda, 2019). Definite trilete spores, produced by tracheophytes, occur in the Sandbian Dalby Limestone within the Baltonidus gerdae conodont sub-zone (Rubinstein \& Vajda, 2019). Non-marine palynological data from Gotland is sparse and results have so far only been published from the nearshore deltaic successions of the Burgsvik Formation, southern Gotland (Gray et al. 1974, Sherwood-Pike \& Gray 1985, Hagström, 1997; Hagström \& Mehlqvist, 2012). The palynomorph assemblages of the Burgsvik Formation are typified by cryptospores, such as Laveolancis spp. Tetrahedraletes medinensis and Acontotetras gotlandica, together with granulate trilete spores, such as Apiculiretusispora burgsvikensis and the tetrad Pachytetras rugosa (Hagström 1997; VV. unpublished data).

The record of upper Silurian palynological successions is better known from Skåne, mainly through the detailed studies of Mehlqvist et al. (2012, 2014a, 2014b, 2015). The Burgsvik Sandstone and Burgen Oolite are coeval with the successions belonging to the Klinta Formation in Skåne. The Oz. snajdri Biozone and the succeeding Oz. crispa Biozone correspond to the Synerisporites inframurinata (spore) sub-zone by Burgess \& Richardson (1995). This spore zone is typified by an early land plant flora of both cryptosporesproducing liverworts and trilete spore-producing tracheophytes (e.g. Cooksonia), both in Skåne and on southern Gotland, Burgsvik Sandstone. Within this zone, the spore assemblages are dominated by the long-ranging cryptospores attributable to Dyadospora and Laevolancis, together with trilete spores of Ambitisporites. Stratigraphically significant spore taxa in the Oz. snajdri interval in both Skåne and on southern Gotland, include Synorisporites cf. libycus, Hispanaediscus verrucatus and H. major, all typical of a Ludlow age. No palynological analyses have yet been carried out on the strata exposed in the Burgen outlier but there is no reason to suspect that the palynological successions differ from those of the succession at Burgsvik.

\subsection{Integration of bio- and chemostratigraphy}

Very high $\delta^{13} C_{\text {carb }}$ values and the abundance of oncoids at Burgen 9 and Kapellet 1 are suggestive of a stratigraphic position similar to the Upper Eke Formation (Fig. 10, arrow B), as this interval has been previously assumed to record the highest $\delta^{13} C_{\text {carb }}$ values of the LCIE in Gotland (Samtleben et al., 2000; Eriksson \& Calner, 2008). But, as noted in the 
introduction, chemostratigraphic correlation across the LCIE is complicated by diachronous development of $\delta^{13} C_{\text {carb }}$ trends across the onshore-offshore gradient, as observed also for other isotope excursions (LaPorte et al., 2009; Jarochowska \& Munnecke, 2015; Danise et al., 2020; Ray et al., 2020). Considering how rapidly the excursion developed globally (Melchin et al., 2020; Sproson, 2020), it is possible that the $\delta^{13} C_{\text {carb }}$ of dissolved inorganic carbon in the seawater changed at a higher pace than the lateral migration of facies and the associated migration of conodont taxa attached to specific environments (Jarochowska et al., 2017). Therefore an integration of new sedimentological evidence, chemo- and biostratigraphy is presented here, pointing to the correlation of the described strata in the Burgen outlier with the Burgen Oolite Formation and the locally occurring second peak of the LCIE (Fig. 10, arrow A):

1. Previous $\delta^{13} C_{\text {carb }}$ data indicated $\delta^{13} C_{\text {carb }}$ values in the Burgen Oolite Formation reaching around $+7 \%$ (Samtleben et al., 2000; Eriksson \& Calner, 2008), although additional samples listed by Samtleben et al. (2000) show values up to $8.7 \%$ o at Närshamn 4, i.e. comparable with those obtained here at Burgen 9.

2. The occurrences of 'Oz.' eosteinhornensis 'scanica' and Oz. snajdri at Burgen 7, 9 and at Glasskkär 1 exclude the possibility that the strata correlate with the Upper Eke Formation, although they are very similar in terms of facies and $\delta^{13} C_{\text {carb }}$ values. The younger age is supported by the co-occurrence of 'Oz.' eosteinhornensis 'scanica' in the lowering limb of the LCIE in the eastern part of the Baltic Basin (Spiridonov et al., 2017, 2020a).

3. Carbon isotope values correspond to either the Burgen Oolite Formation in the Uddvide-1 core (Fig. 10, arrow A) at the base of the lowering limb of the LCIE or to the rising limb in the Eke Formation in the Burgen core (the interval between -10 and -12 m; Calner \& Eriksson, 2006; Eriksson \& Calner, 2008) and the Uddvide-1 core (around -35 m; Younes et al., 2017, Fig. 10, arrow B). Based on conodont fauna (see chapter 4.2 above), variant A (younger) is here held as better supported.

4. The similarity suggested by the presence of oncoids is misleading, as the base of the Burgen Oolite Formation at Kapellet 1 represents a different depositional environment than the Upper Eke Formation throughout Gotland. The oncoids are formed in a fully-marine high-energy environment with diverse fauna, in the proximity of reefs. A similar facies is present in the base of the member in the Uddvide 1 core (Younes, 2012, Fig. 8E). 


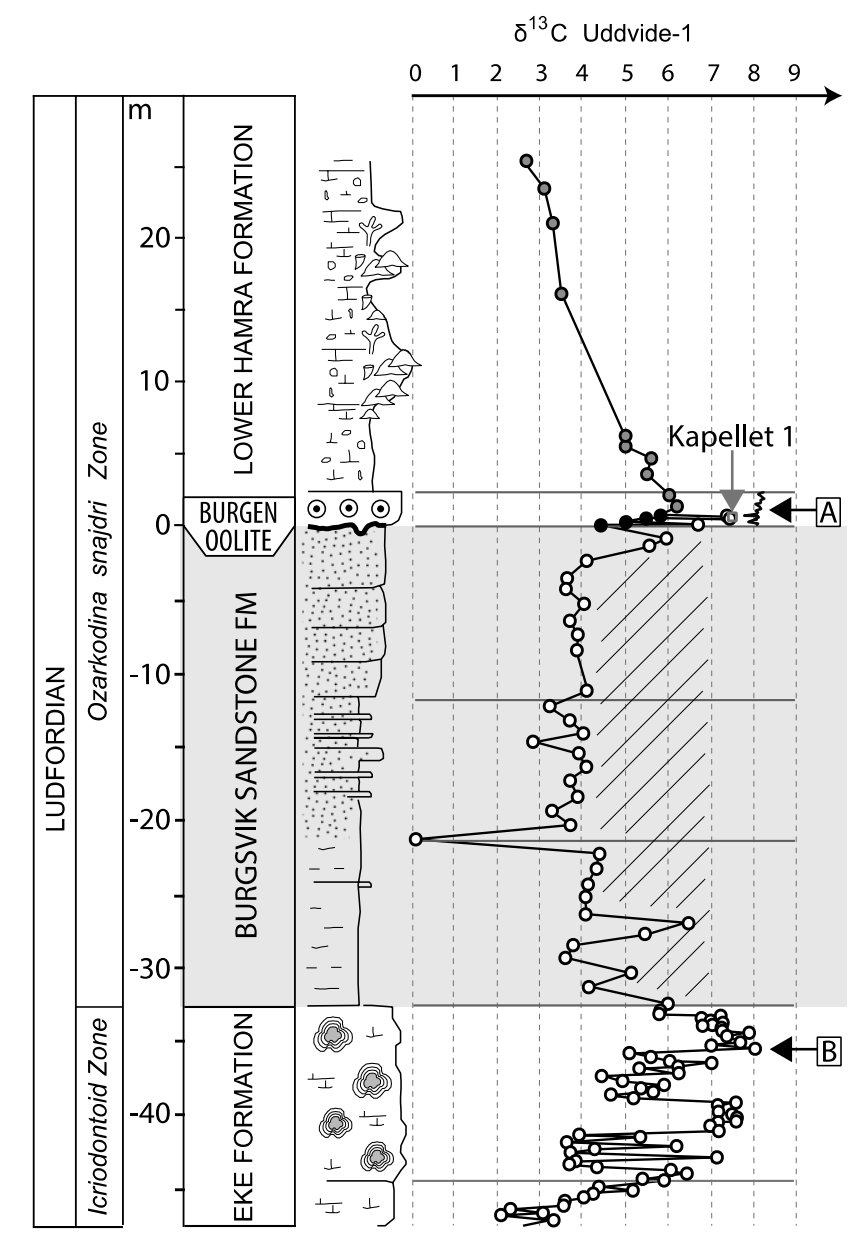

Figure 10. Correlation of Burgen 9 and Kapellet 1 sections with facies and $\delta^{13} C$ stratigraphy in the composite profile from Younes et al. (2017), which was compiled from Uddvide-1 core (white dots), Husryggen 4 (black dots) and Hoburgen (grey dots). The arrow marked A indicates the proposed correlation of the Burgen 9 section, with B being the alternative discussed in the text. The gray square is the proposed correlation of the Kapellet 1 section (based on isotope values from sample PMU 23104, Fig. 7C).

The depositional environment of the Burgen Oolite Formation in the Burgen outlier was slightly more protected and heterogeneous than the well-sorted oolitic shoal exposed in the Sudret peninsula. This might explain a higher diversity of conodonts in this area. It is also in line with the observed spatial gradient of $\delta^{13} C_{\text {carb }}$ values, which are often highest in platform-top settings. Nonetheless, faunal diversity and proliferation of reefs are not compatible with the interpretation of microbial carbonates forming reefs and contributing to reef formation as 'disaster forms'. Similar observations have been made by Vennin et al. (2015) in the Lower Triassic, which is commonly interpreted as dominated by 'anachronistic' microbial carbonates owing to reduced grazing, but can also be important contributors to a 'healthy' carbonate factory. Reefs described in Burgen 9 form small structures in outcrops, but seismic profiles east of Gotland indicate that much larger barrier reefs developed at that time (Bjerkéus \& Eriksson, 2001), suggesting that already at this time a diverse reef-building 
fauna recolonized the carbonate platform, leading up to the proliferation of reefs in the overlying Hamra Formation.

\section{6. 'Oz. scanica' and the steinhornensis-remscheidensis conundrum}

'Oz. scanica' was originally introduced by Jeppsson (1974) as 'Oz. steinhornensis scanica'. The original species Spathognathodus steinhornensis Ziegler, 1956 and Sp. remscheidensis Ziegler, 1960 are form taxa based on $P_{1}$ elements. The latter form species has subsequently been placed in the rank of subspecies of the former by Walliser (1964), who considered both of them to form a succession of subspecies, which he arbitrarily separated based on their occurrence before and after the first appearance of Icriodus woschmidti. Walliser (1964) also postulated that distinguishing the two forms required large collections and was often impossible for individual specimens. Klapper and Murphy (1974) assigned both subspecies to the multielement genus Ozarkodina but excluded the steinhornensis species from this genus based on the presence of a 'diplododellan' (possessing a denticulate posterior, i.e. caudal, process) $S_{0}$ element, which they proposed to be diagnostic for Pandorinella and absent in Ozarkodina. However, Murphy et al. (2004) noted that this character appeared independently in multiple lineages and could not be used as a sole basis for assignment to either Pandorinellina or Ozarkodina. Based on the shape of the denticulation and the basal cavity, they referred the steinhornensis material of Ziegler (1956) and a steinhornensis bedding plane assemblage (Mashkova, 1972) to the genus Criteriognathus Walliser, 1972.

Following the exclusion of the steinhornensis species from Ozarkodina, Klapper and Murphy (1974) assigned former subspecies of Sp. steinhornensis to Oz. remscheidensis (as the second available name with priority) and formulated a differential diagnosis that distinguished $\mathrm{Oz}$. remscheidensis eosteinhornensis based on a nearly uniform height of denticles in its $\mathrm{P}_{1}$ element from $\mathrm{Oz}$. remscheidensis remscheidensis with irregular denticle heights. According to this revision, $\mathrm{Oz}$. steinhornensis scanica should be referred to as $\mathrm{Oz}$. remscheidensis scanica, because in Jeppsson's (1974) reconstruction it does not have a caudal process. Instead, in his later articles Jeppsson used 'Oz. scanica', i.e. in the rank of species distinct from Oz. remscheidensis (Jeppsson, 2005; Jeppsson et al., 2006), but provided no taxonomic discussion of this decision. This is further complicated by the subsequent revision of $\mathrm{Oz}$. remscheidensis placing it in a new genus Zieglerodina. Based on the type material, Murphy et al. (2004) excluded the remscheidensis species as described by Ziegler (1960) from Ozarkodina based on 'a more posterior position and shape and, generally, the larger size of the basal platform lobes, the alternation of denticle sizes, undulation of the processes of the 
transition-series elements, and less deep distribution of white matter in all elements' in $\mathrm{P}_{1}$ elements and alternating large and small denticles in $S_{1}$ through $S_{4}$ denticles. They excluded the eosteinhornensis subspecies from Zieglerodina and proposed that it might be placed in a separate genus, provisionally distinguished as ' $W$ '. Until this genus is documented, current practice puts the eosteinhornensis form in the rank of species within Ozarkodina (Corradini \& Corriga, 2012), although it is also expressed as 'Ozarkodina' to highlight the uncertainty and this approach is adopted here.

A cladistic analysis by Donoghue et al. (2008) taking into account four published reconstructions of the apparatus resolved 'Oz.' remscheidensis in one clade with Nicollidina brevis (Bischoff \& Ziegler, 1957) and Oz. confluens (the type species of the genus) as a sister taxon to this clade. Nicollidina Dzik, 2002 would have priority over Zieglerodina Murphy et al., 2004, but a comparative analysis is lacking and it remains unresolved whether brevis and remscheidensis belong to the same genus (in this case it would have to be Nicollidina) or if their morphological disparity warrants assignment to two genera. The analysis did not include other species relevant to establishing the relationships between $\mathrm{Zi}$. remscheidensis, $\mathrm{Cr}$. steinhornensis and the eosteinhornensis species as the latter two lack complete reconstructions.

It remains to be clarified where the scanica form belongs in these taxa. Further subspecies of Oz. remscheidensis have been introduced by Miller and Aldridge (1997) based on British material, but reports of $\mathrm{Oz}$. remscheidensis scanica or $\mathrm{Oz}$. scanica have been minimal. Viira (1982) reported 'Oz. steinhornensis steinhornensis aff. Oz. st. scanica' from the Ludlow of East Baltic and Helfrich (1978) reported 'Oz. steinhornensis scanica' from the SilurianDevonian transition in Virginia. The latter identification requires revision, since the specimens illustrated by Helfrich (1978) have clearly falling distal ends of both processes in the $\mathrm{P}_{1}$ element, whereas the type scanica collection is characterized by aboral margins of $\mathrm{P}_{1}$ elements forming a nearly straight line. Other diagnostic features are unfortunately unrecognizable in Helfrich's (1978) illustrations and no description is provided. Apart from these two reports, 'Oz. scanica' is only known in L. Jeppsson's collections from Scania and Gotland. Based on the type collection, its assignment to Zieglerodina can be excluded as it lacks alternating denticles in the S element series and irregularly distributed lengths of denticles in the $\mathrm{P}_{1}$ elements. The type collection of 'Oz. scanica' comes from Scania and has not been examined in this study, therefore a conclusive revision was not possible. This form is here provisionally referred to as 'Oz. eosteinhornensis scanica'. Other forms, identified by Jeppsson as 'Oz. steinhornensis', and referable to Oz. steinhornensis ssp. 1 and ssp. 2 from the Přídolí of Scania (Jeppsson, 1974) were also found in the Ludfordian Eke, Burgen and 
Jarochowska et al., Revision of thelodonts, acanthodians, conodonts...

Hamra formations, and are here referred to as 'Oz.' eosteinhornensis (non scanica) until the type material can be revised.

\subsection{The subspecies problem}

A number of conodont taxa in this study have been moved between the ranks of species and subspecies, e.g. Oulodus excavatus excavatus, Oulodus excavatus novoexcavatus, 'Ozarkodina' eosteinhornensis scanica, or Zieglerodina remscheidensis. In Jeppsson's articles the rank changes took place implicitly, without discussing the species concept and criteria (e.g. Jeppsson, 1972, 2005). This is a widespread practice in conodont taxonomy and a large part of the Silurian zonations on Gotland and elsewhere relies on subspecies (e.g. Jeppsson et al., 2006; Märss \& Männik, 2013; Corradini et al., 2015). The use of subspecies (particularly with such a volatile status) is a hindrance in diversity and evolutionary analyses, or, as put by Mayr (1982), 'the entering of a wedge of destruction of a purely essentialistically defined species'. The popularity of subspecies in conodont taxonomy may reflect the fact that it relies on organs in which the morphology is strongly bound to the food-processing function and therefore to the biotic environment and the food base. Morphological variability of conodonts can be expected to vary along clines in these parameters, reflecting ecological and microevolutionary processes that the trinomials cannot capture.

The following approach is adopted here: the description of regional populations representing a constrained proportion of the intraspecific variation can be achieved through specifying the locality and age (e.g. 'Oz.' steinhornensis from the Burgen Oolite Formation in the Ludfordian of Gotland) without producing a redundancy of Latin names. A morphologically distinct population in this sense may exist only fleetingly and will not be identical with any other population, making a trinomial dedicated to this population obsolete. Thus, following the reasoning of Wilson and Brown (1953), we adopt here the convention that morphologies showing the same unique combination of traits supraregionally can be validated as the same species, whereas endemic morphologies may represent either populations within existing taxa or new species, but not subspecies.

With respect to the conodont fauna in the Burgen Oolite Formation, two taxa originally described in the rank of subspecies, Oulodus excavatus excavatus and Ou. ex. novoexcavatus, are reported exclusively from Gotland, where they co-occur in the same samples starting from the upper Eke Formation. Silurian collections in Estonia (Männik, 2010) and our (Jarochowska et al., 2018) observations from the Silurian of England indicate that 'Ou. ex. excavatus' occurs outside Gotland. Based on a comparison of its apparatus with 
Jarochowska et al., Revision of thelodonts, acanthodians, conodonts...

Ou. cristagalli Ziegler, 1960, Wickström (2005) proposed that the latter should be regarded as a synonym of Ou. excavatus, which would extend its occurrence to the upper Silurian and Lower Devonian of North America. The consistent co-occurrence of Ou. excavatus and $\mathrm{Ou}$. novoexcavatus and the lack of transitional forms between them (novoexcavatus is easily distinguishable by a twisted tip of the basal cavity) and their disparate although overlapping stratigraphic ranges warrant their distinction as separate species. The lack of recognition of $\mathrm{Ou}$. novoexcavatus outside Gotland may be related to the paucity of published illustrations and descriptions of this species (exclusively in Jeppsson, 1972) and to the fact that the diagnostic character is not recognizable under SEM.

\section{Conclusions}

1. Revision of conodont faunas in Lennart Jeppsson's collection documented the occurrence of 'Oz.' eosteinhornensis 'scanica', Oz. crispa and Oz. snajdri in the Burgen outlier. These occurrences support placing the Burgen Oolite Formation in this area in the Ozarkodina snajdri Biozone sensu Jeppsson et al. (2006).

2. Conodont species richness in this area is estimated at a minimum of 21 species. This includes 'Ozarkodina' eosteinhornensis, which occurs as the 'scanica' form as well as the 'non scanica' form corresponding to the original description of Walliser (1964). Previously reported Aldridgeodus minimus? and Panderodus serratus could not be confirmed in re-examined samples, but a specimen of Ozarkodina wimani is herein revised as the shallow-water species Zieglerodina inordinata (Viira, 2000) previously only known from the Př́dolí of the eastern Baltic basin and Oklahoma.

3. The fish fauna from the Burgen outlier comprise an estimated nine species, chiefly represented by thelodonts that indicate a late- rather than mid-Ludlow age.

4. The facies in the Burgen outlier correspond to a more protected and heterogeneous environment compared with the Burgen Oolite Formation in the Sudret peninsula. The Burgen succession includes crinoidal, ooidal and bioclastic-oncoidal shoals and patch reefs formed by a diverse, fully marine fauna with a microbial contribution. The deposition took place above the wave base, in a fully marine, well oxygenated water. The high diversity of metazoan carbonate producers indicates a recovery from the impoverishment in the microbially-dominated underlying Eke Formation.

5. The $\delta^{13} C_{\text {carb }}$ values reach $+9.2 \%$ at Burgen 9 and are correlated here with the Burgen Oolite Formation in the Uddvide-1 core. The higher values in the Burgen outlier may reflect an onshore-offshore gradient across the carbonate platform. 
6. A boundary between the Burgsvik Sandstone Formation and the Burgen Oolite Formation has been identified at Kapellet 1 , with $\delta^{13} C_{\text {carb }}$ values of $+7.5 \%$.

7. Our data indicates a restoration of diverse conodont, benthic, and fish faunas as the LCIE was starting to wane. The NE-SW gradient in conodont diversity and $\delta^{13} C_{\text {carb }}$ values across the Burgen Oolite Formation points to a facies contribution to previously recorded changes associated with the LCIE.

\section{Acknowledgements}

We thank Axel Munnecke, Carl Reddin, Salim Belkhedim and Agnese Bonomo for help in fieldwork, Michael Joachimski for isotope measurements, Birgit Leipner-Mata for help with preparing thin sections, and Git Klintvik Ahlberg for extracting the fish microremains. The authors also thank Michael Streng (Uppsala University) for helping us with the SEM-work and Linda Wickström (SGU) for giving access to data that helped produce the maps in this work. We are grateful to Mikael Calner, Andrej Spiridonov and an anonymous reviewer for constructive suggestions, which improved the manuscript substantially. EJ was supported by Deutsche Forschungsgemeinschaft (grant no Ja 2718/1-1) and EU FP7 SYNTHESYS (SETAF-5040). The field work of OB was funded by Helge Ax:son Johnsons stiftelse. We acknowledge funding from the Swedish Research Council VR No. 2019-4061 to V.V.

\section{Data availability statement}

The data that support the findings of this study are openly available in the Open Science Framework repository at DOI 10.17605/OSF.IO/GTMA7

\section{References}

Agassiz, L., 1838, On the fishes of the ludlow rocks, or upper beds of the Silurian system: Report of the British association for the advancement of science, p. 1-91.

Aldridge, R. J., and Schönlaub, H. P., 1989, Conodonts, in Holland, C. H., and Bassett, M. G., eds., A Global Standard for the Silurian System: Cardiff, National Museum of Wales, p. 274-279.

Armstrong, H. A., 1990, Conodonts from the Upper Ordovician-Lower Silurian carbonate platform of North Greenland: Grønlands Geologiske Undersøgelse, Bulletin, v. 159, p. $1-151$.

Badawy, A. S., Mehlqvist, K., Vajda, V., Ahlberg, P., and Calner, M., 2014, Late Ordovician (Katian) spores in Sweden: oldest land plant remains from Baltica: GFF, v. 136, no. 1, p. 16-21.

Bickert, T., Pätzold, J., Samtleben, C., and Munnecke, A., 1997, Paleoenvironmental changes in the Silurian indicated by stable isotopes in brachiopod shells from Gotland, Sweden: Geochimica et cosmochimica Acta, v. 61, no. 13, p. 2717-2730. 
Bischoff, G., and Ziegler, W., 1957, Die Conodontenchronologie des Mitteldevons und des tiefsten Oberdevons: Abhandlungen des Hessischen Landesamtes für Bodenforschung zu Wiesbaden, v. 22, p. 1-136.

Bjerkéus, M., and Eriksson, M., 2001, Late Silurian reef development in the Baltic Sea: GFF, v. 123 , no. 3 , p. $169-179$.

Blom, H., Märss, T., and Miller, C. G., 2002, Silurian and earliest Devonian birkeniid anaspids from the Northern Hemisphere: Earth and Environmental Science Transactions of the Royal Society of Edinburgh, v. 92, no. 03, p. 263-323.

Bremer, O., and Blom, H., 2015, An updated stratigraphic and environmental framework for the distribution of Silurian vertebrates on Gotland: Estonian Journal of Earth Sciences, v. 64, no. 1, p. 13-18.

Bremer, O., Jarochowska, E., and Märss, T., 2020, Vertebrate remains and conodonts in the upper Silurian Hamra and Sundre formations of Gotland, Sweden: GFF, v. 142, no. 1, p. 52-80.

Bremer, O., Niedźwiedzki, G., Blom, H., Dec, M., and Kozłowski, W., 2018, Vertebrate microremains from the upper Silurian Winnica Formation of the Holy Cross Mountains, Poland: Geological Magazine, v. 155, no. 7, p. 1523-1541.

Brotzen, F., 1934, Erster Nachweis von Unterdevon im Ostseegebiete durch Konglomeratgeschiebe mit Fischresten. II Teil (Paläontologie): Zeitschrift für Geschiebeforschung, v. 10, p. 1-65.

Burgess, N. D., and Richardson, J. B., 1995, Late Wenlock to Early Přídolí cryptospores and miospores from south and southwest Wales, Great Britain: Palaeontographica B, v. 236, p. 1-44.

Calner, M., 2005, Silurian carbonate platforms and extinction events-ecosystem changes exemplified from Gotland, Sweden: Facies, v. 51, no. 1, p. 584-591.

Calner, M., and Eriksson, M. J., 2006, Evidence for rapid environmental changes in low latitudes during the Late Silurian Lau Event: the Burgen-1 drillcore, Gotland, Sweden: Geological Magazine, v. 143, no. 01, p. 15-24.

Calner, M., Eriksson, M. E., Clarkson, E. N. K., and Jeppsson, L., 2008, An atypical intraplatform environment and biota from the Silurian of Gotland, Sweden: GFF, v. 130, p. 79-86.Carls, P., Slavik, L., and Valenzuela-Rios, J. I., 2007, Revisions of conodont biostratigraphy across the Silurian-Devonian boundary: Bulletin of Geosciences, v. 82, no. 2, p. 145-164.

Corradini, C., and Corriga, M. G., 2012, A Přídolí-Lochkovian conodont zonation in Sardinia and the Carnic Alps: implications for a global zonation scheme: Bulletin of Geosciences, v. 87, no. 4, p. 635-650.

Corradini, C., and Serpagli, E., 1999, A Silurian conodont biozonation from late Llandovery to end Pridoli in Sardinia: Bollettino della Società Paleontologica Italiana, v. 37, no. 2-3, p. 255-273.

Corradini, C., Corriga, M. G., Männik, P., and Schönlaub, H. P., 2015, Revised conodont stratigraphy of the Cellon section (Silurian, Carnic Alps): Lethaia, v. 48, no. 1, p. 5671.

Danise, S., Price, G. D., Alberti, M., and Holland, S. M., 2020, Isotopic evidence for partial geochemical decoupling between a Jurassic epicontinental sea and the open ocean: Gondwana Research, v. 82, p. 97-107Donoghue, P. C. J., Purnell, M. A., Aldridge, R. J., and Zhang, S., 2008, The interrelationships of 'complex' conodonts (Vertebrata): Journal of Systematic Palaeontology, v. 6, no. 2, p. 119-153.

Dzik, J., 2002, Emergence and collapse of the Frasnian conodont and ammonoid communities in the Holy Cross Mountains, Poland: Acta Palaeontologica Polonica, v. 47 , no. 4, p. 565-650. 
Einasto, R., and Viira, V., 2003, Wenlock-Ludlow boundary beds and conodonts of Saaremaa Island, Estonia: Proceedings of the Estonian Academy of Sciences, Geology, v. 52, no. 4 , p. 213-238.

Eriksson, M. J. E., and Calner, M., 2008, A sequence stratigraphical model for the Late Ludfordian (Silurian) of Gotland, Sweden: implications for timing between changes in sea level, palaeoecology, and the global carbon cycle: Facies, v. 54, no. 2, p. 253276.

Eriksson, M. E., Nilsson, E. K., and Jeppsson, L., 2009, Vertebrate extinctions and reorganizations during the Late Silurian Lau Event: Geology, v. 37, no. 8, p. 739-742.

Erlström, M., Persson, L., Sivhed, U., and Wickström, L., 2009, Beskrivning till regional berggrundskarta över Gotlands län: Sveriges geologiska undersökning, v. K 221.

Fredholm, D., 1988a, Vertebrate biostratigraphy of the Ludlovian Hemse Beds of Gotland, Sweden: Geologiska Föreningen i Stockholm Förhandlingar, v. 110, no. 3, p. 237253.

-, 1988b, Vertebrates in the Ludlovian Hemse Beds of Gotland, Sweden: Geologiska Föreningen i Stockholm Förhandlingar, v. 110, no. 2, p. 157-179.

-, 1989, Silurian vertebrates of Gotland, SwedenPh. D]: Lund University, 47 p.

-, 1990, Agnathan vertebrates in the Lower Silurian of Gotland, Sweden: Geologiska Föreningen i Stockholm Förhandlingar, v. 112, no. 1, p. 61-80.

Gray, J., Laufeld, S., and Boucot, A. J., 1974, Silurian Trilete Spores and Spore Tetrads from Gotland: Their Implications for Land Plant Evolution: Science, v. 185, p. 260-263.

Gray, J. and Boucot, A.J., 1977, Early vascular land plants: proof and conjecture: Lethaia, v. 10, p. 145-174.

Gross, W., 1947, Die Agnathen und Acanthodier des obersilurischen Beyrichienkalks: Palaeontographica Abteilung A, v. 96, p. 91-158.

-, 1968, Die Agnathen-Fauna der Silurischen Halla-Schichten Gotlands: Geologiska Föreningen i Stockholm Förhandlingar, v. 90, no. 3, p. 369-400.

Hagström, J., 1997, Land-derived palynomorphs from the Silurian of Gotland, Sweden: GFF, v. 119, no. 4, p. 301-316.

Hagström, J., and Mehlqvist, K., 2012, The dawn of terrestrial ecosystems on Baltica: First report on land plant remains and arthropod coprolites from the Upper Silurian of Gotland, Sweden: Palaeogeography, Palaeoclimatology, Palaeoecology, v. 317-318, p. 162-170.

Hede, J. E., 1919, Djupborrningen vid Burgsvik på Gottland 1915. Paleontologiskstratigrafiska resultat: Sveriges Geologiska Undersökning, v. C298, p. 1-59.

-, 1921, Gottlands Silurstratigrafi: Sveriges Geololgiska Undersökning, v. C305, p. 1-100.

-, 1960, The Silurian of Gotland, in Regnéll, G., and Hede, J. E., eds., The Lower Palaeozoic of Scania. The Silurian of Gotland. Guide to Excursions Nos A 22 and C 17, Volume XXI Session: Stockholm, Sweden, Sveriges Geologiska Undersökning, p. 44-87.

Helfrich, C. T., 1978, A conodont fauna from the Keyser Limestone of Virginia and West Virginia: Journal of Paleontology, v. 52, no. 5, p. 1133-1142.

Jarochowska, E., and Munnecke, A., 2015, Silurian carbonate high-energy deposits of potential tsunami origin: Distinguishing lateral redeposition and time averaging using carbon isotope chemostratigraphy: Sedimentary Geology, v. 315, p. 14-28.

Jarochowska, E., Bremer, O., Yiu, A., Märss, T., Blom, H., Mörs, T., and Vajda, V., 2020b, Revision of thelodonts, acanthodians, conodonts, and the depositional environments in the Burgen outlier (Ludlow, Silurian) of Gotland, Sweden. Supporting data at https://osf.io/gtma7 (DOI 10.17605/OSF.IO/GTMA7) 
Jarochowska, E., Munnecke, A., Frisch, K., Ray, D. C., and Castagner, A., 2016, Faunal and facies changes through the mid Homerian (late Wenlock, Silurian) positive carbon isotope excursion in Podolia, western Ukraine: Lethaia, v. 49, no. 2, p. 170-198.

Jarochowska, E., Nohl, T., Grohganz, M., Hohmann, N., Vandenbroucke, T. R. A., and Munnecke, A., 2020a, Reconstructing depositional rates and their effect on paleoenvironmental proxies: the case of the Lau Carbon Isotope Excursion in Gotland, Sweden: Paleoceanography and Paleoclimatology, p. e2020PA003979.

Jarochowska, E., Ray, D. C., Röstel, P., Worton, G. J., and Munnecke, A., 2018, Harnessing stratigraphical bias at the section scale: conodont diversity in the Homerian (Silurian) of the Midland Platform, England: Palaeontology, v. 61, no. 1, p. 57-76.

Jarochowska, E., Viira, V., Einasto, R., Nawrot, R., Bremer, O., Männik, P., and Munnecke, A., 2017, Conodonts in Silurian hypersaline environments: Specialized and unexpectedly diverse: Geology, v. 45, no. 1, p. 3-6.

Jeppsson, L., 1972, Some Silurian conodont apparatuses and possible conodont dimorphism: Geologica et Palaeontologica, v. 6, p. 51-69.

-, 1974, Aspects of late Silurian conodonts: Fossils and Strata, v. 6, p. 1-54.

-, 1983, Silurian conodont faunas from Gotland: Fossils and Strata, v. 15, p. 121-144.

-, 1987, Lithological and conodont distributional evidence for episodes of anomalous oceanic conditions during the Silurian, Department of Geology, University of Lund.

-, 2005, Conodont-based revisions of the Late Ludfordian on Gotland, Sweden: GFF, v. 127, no. 4, p. 273-282.

Jeppsson, L., and Aldridge, R. J., 2000, Ludlow (late Silurian) oceanic episodes and events: Journal of the Geological Society, v. 157, no. 6, p. 1137-1148.

Jeppsson, L., and Anehus, R., 1995, A buffered formic acid technique for conodont extraction: Journal of Paleontology, v. 69, no. 4, p. 790-794.

Jeppsson, L., Eriksson, M. E., and Calner, M., 2006, A latest Llandovery to latest Ludlow high-resolution biostratigraphy based on the Silurian of Gotland-a summary: GFF, v. 128 , no. 2 , p. 109-114.

Jeppsson, L., Talent, J. A., Mawson, R., Andrew, A., Corradini, C., Simpson, A. J., WigforssLange, J., and Schönlaub, H. P., 2012, Late Ludfordian Correlations and the Lau Event, in Talent, J. A., ed., Earth and Life: Global Biodiversity, Extinction Intervals and Biogeographic Perturbations Through Time: Dordrecht, Springer Netherlands, p. 653-675.

Jeppsson, L., Talent, J. A., Mawson, R., Simpson, A. J., Andrew, A. S., Calner, M., Whitford, D. J., Trotter, J. A., Sandström, O., and Caldon, H.-J., 2007, High-resolution Late Silurian correlations between Gotland, Sweden, and the Broken River region, NE Australia: Lithologies, conodonts and isotopes: Palaeogeography, Palaeoclimatology, Palaeoecology, v. 245, no. 1-2, p. 115-137.

Kaljo, D., and Märss, T., 1991, Pattern of some Silurian bioevents: Historical Biology, v. 5, no. 2-4, p. 145-152.

Kaljo, D., Einasto, R., Martma, T., Märss, T., Nestor, V., and Viira, V., 2015, A biochemostratigraphical test of the synchroneity of biozones in the upper Silurian of Estonia and Latvia with some implications for practical stratigraphy: Estonian Journal of Earth Sciences, v. 64, no. 4, p. 267-283.

Kaljo, D., Kiipli, T., and Martma, T., 1997, Carbon isotope event markers through the Wenlock-Pridoli sequence at Ohesaare (Estonia) and Priekule (Latvia):

Palaeogeography, Palaeoclimatology, Palaeoecology, v. 132, no. 1, p. 211223.Klapper, G., and Murphy, M. A., 1974, Silurian-Lower Devonian conodont sequence in the Roberts Mountains Formation of central Nevada: University of California Publications Geological Sciences, v. 111, p. 1-62. 
Koren, T. N., 1987, Graptolite dynamics in Silurian and Devonian time: Bulletin of the Geological Society of Denmark, v. 35, no. 3-4, p. 149-160.

Kozłowski, W., and Munnecke, A., 2010, Stable carbon isotope development and sea-level changes during the Late Ludlow (Silurian) of the Lysogóry region (Rzepin section, Holy Cross Mountains, Poland): Facies, v. 56, no. 4, p. 615-633.

LaPorte, D. F., Holmden, C., Patterson, W. P., Loxton, J. D., Melchin, M. J., Mitchell, C. E., Finney, S. C., and Sheets, H. D., 2009, Local and global perspectives on carbon and nitrogen cycling during the Hirnantian glaciation: Palaeogeography, Palaeoclimatology, Palaeoecology, v. 276, no. 1, p. 182-195.

Larsson, K., 1975, Clastic dikes from the Burgsvik Beds of Gotland: Geologiska Föreningen i Stockholm Förhandlingar, v. 97, no. 2, p. 125-134.

Long, D. G., 1993, The Burgsvik Beds, an Upper Silurian storm generated sand ridge complex in southern Gotland, Sweden: GFF, v. 115, no. 4, p. 299-309.

Loydell, D. K., 2007, Early Silurian positive $\delta^{13} \mathrm{C}$ excursions and their relationship to glaciations, sea-level changes and extinction events: Geological Journal, v. 42, no. 5, p. 531-546.

Männik, P., 2010, Distribution of Ordovician and Silurian conodonts, in Põldvere, A., ed., Viki drill core, Volume 10: Tallinn, Geological Survey of Estonia, p. 21-24.

Manten, A. A., 1971, Silurian reefs of Gotland: Developments in sedimentology, v. 13, p. 539.

Märss, T., 1982, Vertebrate zones in the East Baltic Silurian, in Kaljo, D., and Klaamann, E., eds., Ecostratigraphy of the East Baltic Silurian: Tallinn, Valgus, p. 97--106.

-, 1992, Vertebrate history in the Late Silurian: Proceedings of the Estonian Academy of Sciences, Geology, v. 41, no. 4, p. 204.

-, 2001, Andreolepis (Actinopterygii) in the upper Silurian of northern Eurasia: Proceedings of the Estonian Academy of Sciences, Geology, v. 50, no. 3, p. 174-189.

Märss, T., and Männik, P., 2013, Revision of Silurian vertebrate biozones and their correlation with the conodont succession: Estonian Journal of Earth Sciences, v. 62, no. 4, p. 181-204.

Märss, T., and Miller, C. G., 2004, Thelodonts and distribution of associated conodonts from the Llandovery-lowermost Lochkovian of the Welsh Borderland: Palaeontology, v. 47, no. 5, p. 1211-1265.

Märss, T., Caldwell, M., Gagnier, P. Y., Goujet, D., Männik, P., Martima, T., and Wilson, M., 1998, Distribution of Silurian and Lower Devonian vertebrate microremains and conodonts in the Baillie-Hamilton and Cornwallis Island sections, Canadian Arctic: Proceedings of the Estonian Academy of Sciences, Geology, v. 47, no. 2, p. 51-76.

Mashkova, T. V., 1972, Ozarkodina steinhornensis (Ziegler) apparatus, its conodonts and biozone: Geologica et Palaeontologica, v. SB 1, p. 81-90.

Mayr, E., 1982, Of what use are subspecies?: The Auk, v. 99, no. 3, p. 593-595.

Mehlqvist, K., Larsson, K., and Vajda, V., 2014a, Linking upper Silurian terrestrial and marine successions-Palynological study from Skåne, Sweden: Review of Palaeobotany and Palynology, v. 202, p. 1-14.

Mehlqvist, K., Steemans, P., and Vajda, V., 2015, First evidence of Devonian strata in Sweden - A palynological investigation of Övedskloster drillcores 1 and 2, Skåne, Sweden: Review of Palaeobotany and Palynology, v. 221, p. 144-159.

Mehlqvist, K., Vajda, V., and Steemans, P., 2012, Early land plant spore assemblages from the Late Silurian of Skåne, Sweden: GFF, v. 134, no. 2, p. 133-144.

Mehlqvist, K., Wigforss-Lange, J., and Vajda, V., 2014b, A palynological study from Sweden reveals stable terrestrial environments during Late Silurian extreme marine 
conditions: Earth and Environmental Science Transactions of the Royal Society of Edinburgh, v. 105, no. 3, p. 149-158.

Melchin, M. J., Sadler, P. M., and Cramer, B. D., 2020, The Silurian Period, in Gradstein, F. M., Ogg, J. G., Schmitz, M. D., and Ogg, G. M., eds., Geologic Time Scale 2020, Elsevier, p. 695-732.

Miller, C. G., and Aldridge, R. J., 1997, Ozarkodina remscheidensis plexus conodonts from the upper Ludlow (Silurian) of the Welsh Borderland and Wales: Journal of Micropalaeontology, v. 16, p. 41-49.

Miller, C. G., and Märss, T., 1999, A conodont, thelodont and acanthodian fauna from the Lower Přidoli (Silurian) of the Much Wenlock area, Shropshire: Palaeontology, v. 42, no. 4, p. 691-714.

Munnecke, A., Calner, M., Harper, D. A. T., and Servais, T., 2010, Ordovician and Silurian sea-water chemistry, sea level, and climate: A synopsis: Palaeogeography, Palaeoclimatology, Palaeoecology, v. 296, no. 3-4, p. 389-413.

Munthe, H. W., 1921, Beskrivning till kartbladet Burgsvik jämte Hoburgen och Ytterholmen: Sveriges Geologiska Undersökning, v. Aa, no. 152, p. 172.

Munthe, H. W., Hede, J. E., and von Prost, L., 1924, Beskrivning till kartbladet Ronehamn: Sveriges Geologiska Undersökning, v. Aa, no. 156.

-, 1925, Gotlands geologi: en översikt: Sveriges Geologiska Undersökning, v. C 331, p. 130. Murphy, M. A., Valenzuela-Ríos, J. I., and Carls, P., 2004, On classification of Pridoli (Silurian) - Lochkovian (Devonian) Spathognathodontidae (Conodonts): University of California, Riverside, Campus Museum Contribution, v. 6, p. 1-25.

Nilsson, E. K., 2005: Extinctions and faunal turnovers of early vertebrates during the Late Silurian Lau Event, Gotland, Sweden. Masters thesis, Lund University, Lund. 32 pp.

Pander, C. H., 1856, Monographie der fossilen Fische des silurischen Systems des RussischBaltischen Gouvernements, St. Petersburg, Buchdruckerei der Kaiserlichen Akademie der Wissenschaften.

Peavey, F. N. R., 2013: Review, revision, and paleobiogeography of Ludlow (Silurian) to Lochkovian (Devonian) Spathognathodontid conodont taxa. Ph.D thesis. Texas Tech University, Lubbock, Texas. $121 \mathrm{pp}$.

Ratcliffe, K. T., 1988, Oncoids as environmental indicators in the Much Wenlock Limestone Formation of the English Midlands: Journal of the Geological Society, v. 145, p. 117124.

Ray, D. C., Jarochowska, E., Röstel, P., Worton, G., Munnecke, A., Wheeley, J. R., and Boomer, I., 2020, High-resolution correlation of the Homerian carbon isotope excursion (Silurian) across the interior of the Midland Platform (Avalonia), UK: Geological Magazine, v. 157, no. 4, p. 603-620.

Rexroad, C. B., 1968, Stratigraphy and conodont palaeontology of the Brassfield (Silurian) in the Cincinnati Arch area: Indiana Geological Survey Bulletin, v. 36, p. 1-64.

Richardson, J. B., and McGregor, D. C., 1986, Silurian and Devonian spore zones of the Old Red Sandstone continent and adjacent regions: Geological Survey of Canada, Bulletin v. 364, p. 1-73.

Rubinstein, C. V., and Vajda, V., 2019, Baltica cradle of early land plants? Oldest record of trilete spores and diverse cryptospore assemblages; evidence from Ordovician successions of Sweden: GFF, v. 141, no. 3, p. 181-190.

Samtleben, C., Munnecke, A., and Bickert, T., 2000, Development of facies and C/O-isotopes in transects through the Ludlow of Gotland: evidence for global and local influences on a shallow-marine environment: Facies, v. 43, no. 1, p. 1-38. 
Samtleben, C., Munnecke, A., Bickert, T., and Pätzold, J., 1996, The Silurian of Gotland (Sweden): facies interpretation based on stable isotopes in brachiopod shells:

Geologische Rundschau, v. 85, no. 2, p. 278-292.

Schiøler, P., 1989, Non-toxic low-cost heavy liquid separation in the Geological Survey of Greenland: Rapport Grønlands Geologiske Undersøgelse, v. 145, p. 11-13.

Spiridonov, A., Stankevič, R., Gečas, T., Šilinskas, T., Brazauskas, A., Meidla, T., Ainsaar, L., Musteikis, P. and Radzevičius, S., 2017, Integrated record of Ludlow (Upper Silurian) oceanic geobioevents-Coordination of changes in conodont, and brachiopod faunas, and stable isotopes: Gondwana Research, v. 51, pp. 272-288.

Spiridonov, A., Samsonè, J., Brazauskas, A., Stankevič, R., Meidla, T., Ainsaar, L. and Radzevičius, S., 2020a, Quantifying the community turnover of the uppermost Wenlock and Ludlow (Silurian) conodonts in the Baltic Basin: Palaeogeography, palaeoclimatology, palaeoecology, v. 549, p. 109128.

Spiridonov, A., Stankevič, R., Gečas, T., Brazauskas, A., Kaminskas, D., Musteikis, P., Kaveckas, T., Meidla, T., Bičkauskas, G., Ainsaar, L., and Radzevičius, S., 2020b, Ultra-high resolution multivariate record and multiscale causal analysis of Pridoli (late Silurian): Implications for global stratigraphy, turnover events, and climate-biota interactions: Gondwana Research, v. 86, p. 222-249.

Spjeldnaes, N., 1950, On some vertebrate fossils from Gotland with some comments on the stratigraphy: Arkiv för mineralogi och geologi, v. 8 (1), p. 211-219.

Sproson, A. D., 2020, Pacing of the latest Ordovician and Silurian carbon cycle by a 4.5 Myr orbital cycle: Palaeogeography, Palaeoclimatology, Palaeoecology, v. 540, p. 109543.

Stel, J. H., and de Coo, J. C., 1977, The Silurian Upper Burgsvik and Lower Hamra-Sundre Beds, Gotland: Scripta Geologica, v. 44.

Traquair, R. H., 1898, Report on fossil fishes: Summary of Progress of the Geological Survey of the United Kingdom for 1897, p. 72-76.

Vennin, E., Olivier, N., Brayard, A., Bour, I., Thomazo, C., Escarguel, G., Fara, E., Bylund, K. G., Jenks, J. F., Stephen, D. A., and Hofmann, R., 2015, Microbial deposits in the aftermath of the end-Permian mass extinction: A diverging case from the Mineral Mountains (Utah, USA): Sedimentology, v. 62, no. 3, p. 753-792.

Viira, V., 1982, Late Silurian shallow and deep water conodonts of the East Baltic, in Kaljo, D., and Klaamann, E., eds., Ecostratigraphy of the East Baltic Silurian: Tallinn, Valgus, p. 79-88.

-, 2000, Latest Silurian (Ohesaare Stage) conodonts and the detorta zone in the northern East Baltic: Proceedings of the Estonian Academy of Sciences, Geology, v. 49, no. 1, p. 44-62.

Viira, V., and Aldridge, R. J., 1998, Upper Wenlock to Lower Přídolí (Silurian) conodont biostratigraphy of Saaremaa, Estonia, and a correlation with Britain: Journal of Micropalaeontology, v. 17, no. 1, p. 33-50.

Walliser, O. H., 1964, Conodonten des Silurs: Abhandlungen des Hessischen Landesamtes für Bodenforschung zu Wiesbaden, v. 41, p. 1-106.

-, 1972, Conodont apparatuses in the Silurian: Geologica et Palaeontologica, v. SB1, p. 7579.

Wellman, C. H., Steemans, P., and Vecoli, M., 2013, Palaeophytogeography of OrdovicianSilurian land plants: Geological Society, London, Memoirs, v. 38, p. 461-476.

Wenzel, B., and Joachimski, M. M., 1996, Carbon and oxygen isotopic composition of Silurian brachiopods (Gotland/Sweden): palaeoceanographic implications: Palaeogeography, palaeoclimatology, palaeoecology, v. 122, no. 1-4, p. 143-166. 
Wickström, L. M., 2005: The application of cladistic analysis to lower Palaeozoic conodonts. $\mathrm{Ph} . \mathrm{D}$. thesis. University of Birmingham, Birmingham, UK. $134 \mathrm{pp}$.

Wigforss-Lange, J., 1999, Carbon isotope ${ }^{13} \mathrm{C}$ enrichment in Upper Silurian (Whitcliffian) marine calcareous rocks in Scania, Sweden: GFF, v. 121, no. 4, p. 273-279.

Wilson, E. O., and Brown, W. L., 1953, The subspecies concept and its taxonomic application: Systematic Zoology, v. 2, no. 3, p. 97-111.

Younes, H., 2012: Carbon isotope chemostratigraphy of the Late Silurian Lau Event, Gotland, Sweden. Masters thesis. Lund University, Lund, $44 \mathrm{pp}$.

Younes, H., Calner, M., and Lehnert, O., 2017, The first continuous $\delta^{13} \mathrm{C}$ record across the Late Silurian Lau Event on Gotland, Sweden: GFF, v. 139, no. 1, p. 63-69.

Ziegler, W., 1956, Unterdevonische Conodonten, insbesondere aus dem Schönauer und dem Zorgensis-Kalk: Notizblatt des Hessischen Landesamtes für Bodenforschung, v. 84, p. 93-106.

-, 1960, Conodonten aus dem Rheinischen Unterdevon (Gedinnium) des Remscheider Sattels (Rheinisches Schiefergebirge): Paläontologische Zeitschrift, v. 34, no. 2, p. 169-201. 
Table 1. Distribution of conodont taxa discussed in the Burgen Oolite Formation and adjacent units in Gotland. Uncertain identifications are represented by a ? and a | mean that it has not been found in this unit but ranges through it. All occurrences are compiled from published and unpublished collections of Lennart Jeppsson, hosted at NRM-PZ, except for the new sample G14-26-OB, stored at PMU.

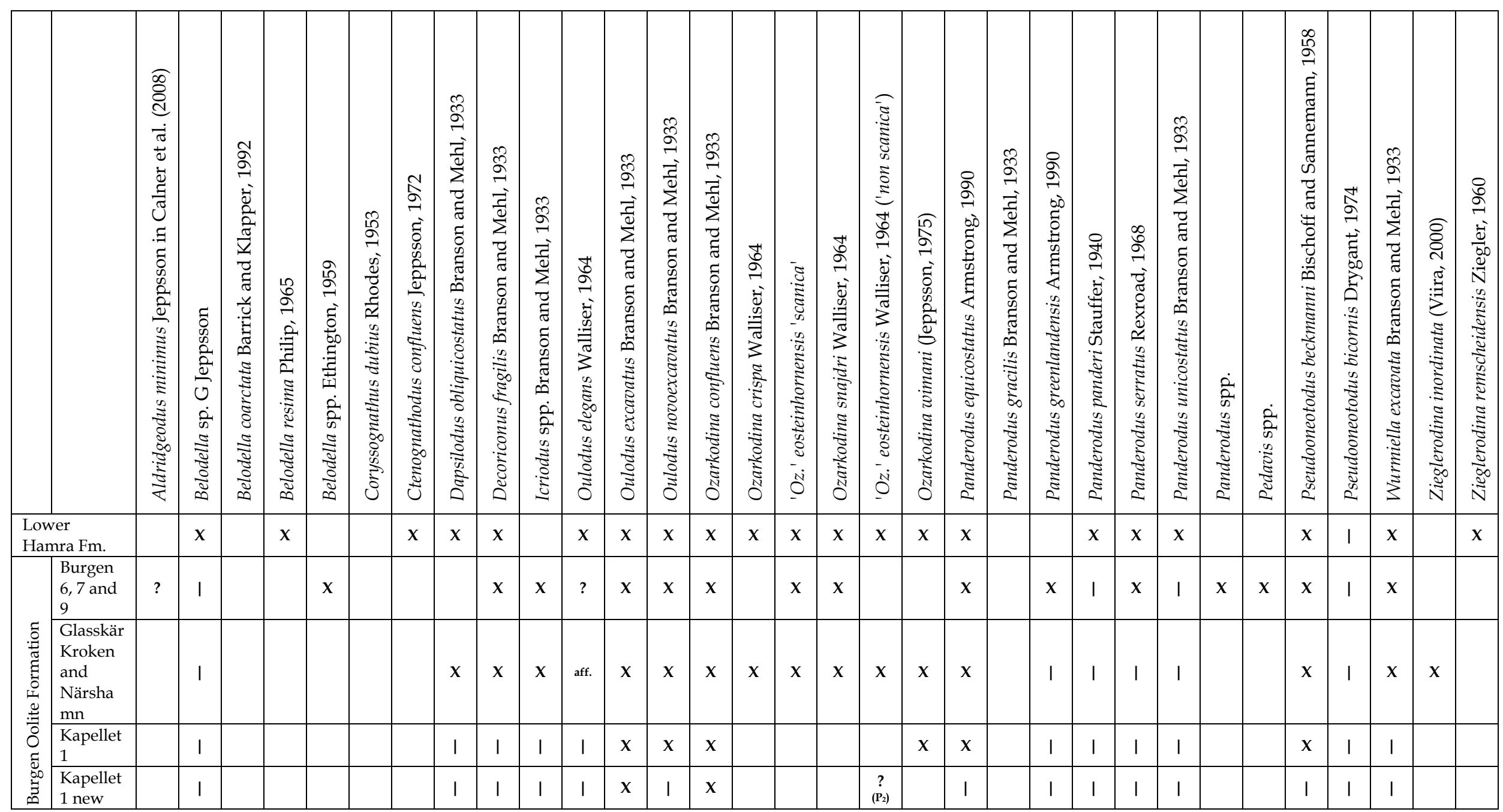


Jarochowska et al., Revision of thelodonts, acanthodians, conodonts...

\begin{tabular}{|l|l|l|l|l|l|l|l|l|l|l|l|l|l|l|l|l|l|l|l|l|l|l|l|l|l|l|l|l|l|l|l|l|}
\hline $\begin{array}{l}\text { sample } \\
\text { G14-26- } \\
\text { OB }\end{array}$ & & & & & & & & & & & & & & & & & & & & & & & & & & & & \\
\hline $\begin{array}{l}\text { Upper Eke } \\
\text { Fm. }\end{array}$ & $\mathrm{I}$ & $\mathrm{x}$ & & & & & $\mathrm{x}$ & $\mathrm{x}$ & $\mathrm{x}$ & $\mathrm{x}$ & $\mathrm{x}$ & $\mathrm{x}$ & $\mathrm{x}$ & & & & $\mathrm{x}$ & & $\mathrm{x}$ & & $\mathrm{I}$ & $\mathrm{I}$ & $\mathrm{x}$ & $\mathrm{x}$ & & $\mathrm{x}$ & $\mathrm{x}$ & $\mathrm{x}$ & & \\
\hline $\begin{array}{l}\text { Middle Eke } \\
\text { Fm. }\end{array}$ & $\mathrm{I}$ & $\mathrm{x}$ & & & & & $\mathrm{x}$ & $\mathrm{x}$ & & & $\mathrm{x}$ & & $\mathrm{x}$ & & & & & & $\mathrm{x}$ & & $\mathrm{I}$ & $\mathrm{I}$ & $\mathrm{x}$ & $\mathrm{x}$ & & $\mathrm{x}$ & $\mathrm{x}$ & $\mathrm{x}$ & \\
\hline $\begin{array}{l}\text { Lower Eke } \\
\text { Fm. }\end{array}$ & $\mathrm{x}$ & $\mathrm{I}$ & & & $\mathrm{x}$ & & $\mathrm{I}$ & $\mathrm{x}$ & & & $\mathrm{x}$ & & $\mathrm{x}$ & & & & & & $\mathrm{x}$ & $\mathrm{x}$ & $\mathrm{I}$ & $\mathrm{I}$ & $\mathrm{x}$ & $\mathrm{x}$ & & & $\mathrm{x}$ & $\mathrm{I}$ & $\mathrm{x}$ & & \\
\hline
\end{tabular}

